Review

\title{
Artificial bioconversion of carbon dioxide
}

\author{
Ting-Ting Zhao a,b, Guang-Hui Feng a,b, Wei Chen b,*, Yan-Fang Song ${ }^{\mathrm{b}}$, Xiao Dong ${ }^{\mathrm{b}}$, \\ Gui-Hua Li b, Hai-Jiao Zhang a, Wei Wei b,c,\# \\ a School of Environmental and Chemical Engineering, Shanghai University, Shanghai 200444, China \\ ${ }^{\mathrm{b}}$ CAS Key Laboratory of Low-carbon Conversion Science and Engineering, Shanghai Advanced Research Institute, Chinese Academy of Sciences, Shanghai \\ 201210, China \\ ' School of Physical Science and Technology, ShanghaiTech University, Shanghai 201210, China
}

\section{A R T I C L E I N F O}

\section{Article history:}

Received 23 March 2019

Accepted 11 May 2019

Published 5 October 2019

\section{Keywords:}

Carbon dioxide

Artificial bioconversion

Solar energy

Carbon fixation

Chemical compound

\begin{abstract}
A B S T R A C T
$\mathrm{CO}_{2}$ is not only the most important greenhouse gas but also an important resource of elemental carbon and oxygen. From the perspective of resource and energy strategy, the conversion of $\mathrm{CO}_{2}$ to chemicals driven by renewable energy is of significance, since it can not only reduce carbon emission by the utilization of $\mathrm{CO}_{2}$ as feedstock but also store low-grade renewable energy as high energy density chemical energy. Although studies on photoelectrocatalytic reduction of $\mathrm{CO}_{2}$ using renewable energy are increasing, artificial bioconversion of $\mathrm{CO}_{2}$ as an important novel pathway to synthesize chemicals has attracted more and more attention. By simulating the natural photosynthesis process of plants and microorganisms, the artificial bioconversion of $\mathrm{CO}_{2}$ can efficiently synthesize chemicals via a designed and constructed artificial photosynthesis system. This review focuses on the recent advancements in artificial bioreduction of $\mathrm{CO}_{2}$, including the key techniques, and artificial biosynthesis of compounds with different carbon numbers. On the basis of the aforementioned discussions, we present the prospects for further development of artificial bioconversion of $\mathrm{CO}_{2}$ to chemicals.
\end{abstract}

(C) 2019, Dalian Institute of Chemical Physics, Chinese Academy of Sciences. Published by Elsevier B.V. All rights reserved.

\section{Introduction}

In 2017, the total world energy consumption was 13.5 billion tons (oil equivalent), of which $87.7 \%$ was sourced from fossil fuels [1]. With the growth in the world population and rapid industrialization of developing countries, the global energy consumption will continue to increase. A large consumption of fossil fuels leads to a rapid increase in the $\mathrm{CO}_{2}$ concentration in the atmosphere, causing serious environmental problems [2]. For sustainable development of human society, there is an urgent need to develop new green technologies to realize the conversion and utilization of $\mathrm{CO}_{2}$ resources $[3,4]$. Although studies on photoelectrocatalysis reduction of $\mathrm{CO}_{2}$ by using renewable energy are increasing, artificial bioconversion of $\mathrm{CO}_{2}$ has attracted more and more attention as an important novel pathway of synthesizing chemicals.

$\mathrm{CO}_{2}$ is an important substantive source for the photosynthesis of plants and microbes on the earth. Organisms absorb $\mathrm{CO}_{2}$

\footnotetext{
* Corresponding author. Tel: +86-21-20350954; Fax: +86-21-20350867; E-mail: chenw@sari.ac.cn

\# Corresponding author. Tel: +86-21-20608005; Fax: +86-21-20350867; E-mail: weiwei@sari.ac.cn

This work was supported by the National Natural Science Foundation of China (91745114, 21802160), the National Key R\&D Program of China (2016YFA0202800), Shanghai Sailing Program (18YF1425700), and Shanghai Advanced Research Institute Innovation Research Program (Y756812ZZ1(172002), Y756803ZZ1(171003)). Wei Chen also acknowledges the support from the Hundred Talents Program of the Chinese Academy of Sciences.

DOI: S1872-2067(19)63408-X | http://www.sciencedirect.com/science/journal/18722067 | Chin. J. Catal., Vol. 40, No. 10, October 2019
} 
from the air and synthesize nutrients with the help of solar energy. However, biological utilization of $\mathrm{CO}_{2}$ is of low efficiency and it is difficult to continuously convert $\mathrm{CO}_{2}$ into synthetic fuels and chemicals on a large scale [5]. In recent years, researchers have made use of microorganisms and enzymes to form biological hybrid systems to absorb $\mathrm{CO}_{2}$, and have used renewable electrical energy and solar energy to produce biochemicals and biofuels. In addition, the photosynthetic autotrophic microbes (cyanobacteria or microalgae) that possess the ability to immobilize $\mathrm{CO}_{2}$ were modified to obtain efficient carbon sequestration organisms through genetic engineering in order to produce high-value target chemicals [6,7].

In general, thermocatalytic conversion of $\mathrm{CO}_{2}$, i.e., $\mathrm{CO}_{2}$ hydrogenation, occurs under harsh reaction conditions such as high temperatures and high pressures, which require large amounts of energy to realize [8]. The source of the reactant hydrogen is also an obstacle for thermocatalytic $\mathrm{CO}_{2}$ hydrogenation. The biggest advantages of $\mathrm{CO}_{2}$ hydrogenation are the relatively satisfactory $\mathrm{CO}_{2}$ conversion rate and the yield of the product methanol. Different from the thermocatalytic conversion of $\mathrm{CO}_{2}, \mathrm{CO}_{2}$ photoreduction, electroreduction, and bioreduction can occur under mild conditions even at ambient temperature and pressure when driven by renewable energy such as solar light and renewable electricity. The efficiencies of the photocatalytic and electrocatalytic reductions of $\mathrm{CO}_{2}$ are relatively higher than that of $\mathrm{CO}_{2}$ bioconversion [9-15], as shown in Table 1. The state-of-the-art biological hybrid system Co-P $|\mathrm{CoPi}|$ R. eutropha exhibited the energy efficiency of $9.7 \%$ [9]. More complicated and valuable compounds can be produced during $\mathrm{CO}_{2}$ bioconversion. Moreover, $\mathrm{CO}_{2}$ artificial bioconversion, which integrates the advantages of photo/electrocatalysis and $\mathrm{CO}_{2}$ bioreduction, shows promise.

Until now, various chemicals have been synthesized by the bioconversion of $\mathrm{CO}_{2}$. This review summarizes the key techniques for $\mathrm{CO}_{2}$ artificial bioconversion and their basic principles, characteristics, etc. Furthermore, the typical chemicals obtained by the aforementioned techniques are classified by their carbon number and exampled. The prospects for further

\section{Table 1}

Energy efficiency comparisons of the various technologies for $\mathrm{CO}_{2}$ conversion.

\begin{tabular}{|c|c|c|c|c|}
\hline Technology & System/Material & Product & $\begin{array}{c}\text { Energy } \\
\text { efficiency } \\
(\%)\end{array}$ & Ref. \\
\hline \multirow{5}{*}{$\begin{array}{c}\text { Artificial } \\
\text { bioconver- } \\
\text { sion }\end{array}$} & \multirow[t]{3}{*}{ Co-P|CoPi| R. eutropha } & Biomass & 9.7 & \multirow[t]{3}{*}{ [9] } \\
\hline & & $\begin{array}{l}\text { Poly(3-hydroxy } \\
\text { butyrate) }\end{array}$ & 7.6 & \\
\hline & & $\mathrm{C}_{3}-\mathrm{C}_{5}$ alcohols & 7.1 & \\
\hline & \multirow{2}{*}{$\begin{array}{c}\text { CoPi } \mid \text { R.eutropha } \mid \text { NiMoZn/ } \\
\text { stainless-steel }\end{array}$} & Biomass & 3.2 & \multirow[t]{2}{*}{ [10] } \\
\hline & & Isopropanol & 0.7 & \\
\hline \multirow[t]{2}{*}{$\begin{array}{l}\text { Photocataly- } \\
\text { sis }\end{array}$} & $\begin{array}{l}\text { GaInP/GaInAs/Ge pho- } \\
\text { tovoltaics }\end{array}$ & $\mathrm{CO}$ & 13.4 & [11] \\
\hline & $\begin{array}{l}\text { Series-connected perov- } \\
\text { skite cells }\end{array}$ & $\mathrm{CO}$ & 6.5 & [12] \\
\hline \multirow{3}{*}{$\begin{array}{l}\text { Electrocataly- } \\
\quad \text { sis }\end{array}$} & - $\mathrm{Ag}_{2} \mathrm{~S}$ in ionic liquids & $\mathrm{CH}_{4}, \mathrm{CO}$ & 58.5 & [13] \\
\hline & Au nanoneedle|NiCoFeP & $\mathrm{CO}$ & 64.0 & [14] \\
\hline & $\mathrm{SnO}_{2}$ quantum wires & $\mathrm{HCOO}^{-}$ & 52.7 & [15] \\
\hline
\end{tabular}

development of artificial bioconversion of $\mathrm{CO}_{2}$ to chemicals are also presented.

\section{Key techniques of $\mathrm{CO}_{2}$ artificial bioconversion}

Artificial bioconversion of $\mathrm{CO}_{2}$ is an important complement to the $\mathrm{CO}_{2}$ conversion aided by renewable energy, besides the $\mathrm{CO}_{2}$ electrocatalytic, photocatalytic, and photoelectrocatalysis conversions. The highlight of $\mathrm{CO}_{2}$ artificial bioconversion is the combination of active biofeatures and physicochemical catalytic sites. Until now, the key techniques of $\mathrm{CO}_{2}$ artificial bioconversion mainly include microbial electrosynthesis (MES), photosynthetic biohybrid systems, PSII (photosystem II) hybrid system, and metabolic engineering.

\subsection{Microbial electrosynthesis}

MES is based on the use of specific microorganisms as biocatalysts in microbial bioelectrochemical systems, with electricity as the source of energy. Reducing $\mathrm{CO}_{2}$ to multi-carbon compounds through biological reactions is one of the most promising emerging technologies (Fig. 1 shows a typical MES system for $\mathrm{CO}_{2}$ reduction) [16-19]. Enzymes are also suitable for the biosynthetic processes in MES (also described in this work) because they share the same function as microorganisms of synthesizing a single product, with a selectivity of $100 \%$ [20]. MES needs electrical energy to provide electrons and to control the electrode potential for $\mathrm{CO}_{2}$ reduction, while the external power supply increases the cost of the whole synthesis process. Previous studies have shown that the overall cost of MES should be further reduced to achieve economic competitiveness and environmental sustainability $[21,22]$. Fortunately, the electrical energy has a wide range of sources and can be regenerated from sustainable forms such as solar, wind, nuclear, and water power, which make MES a green and sustainable $\mathrm{CO}_{2}$ conversion technique [23-26]. However, the widespread use of these renewable energies is limited by their instability and intermittency, which renders the storage and utilization of renewable electricity difficult [27]. The conversion of $\mathrm{CO}_{2}$ into chemicals and biofuels in MES is still in its infancy, and there are many technical and economic challenges that need to be addressed, such as the high power demand and the low

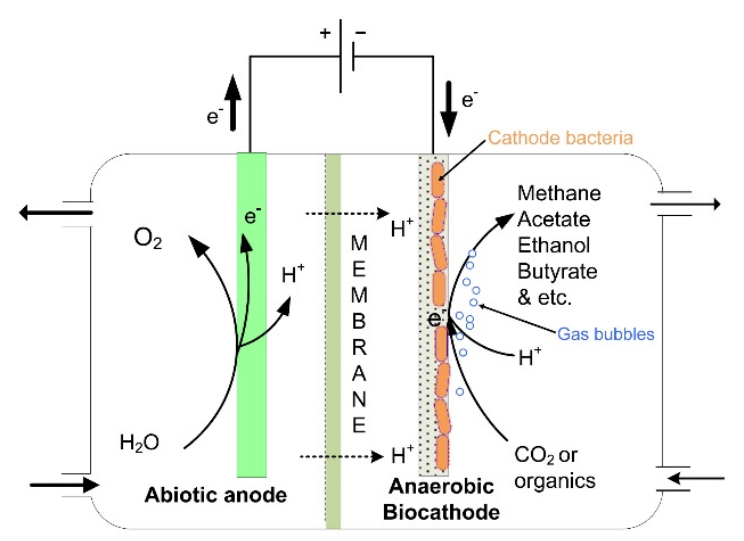

Fig. 1. Scheme of a microbial electrosynthesis system [18]. 
productivity. Despite these challenges, the use of electricity or solar energy as the driving force of biological carbon sequestration has two benefits: first, it can improve the efficiency of biological carbon sequestration; second, solar energy can be stored sustainably in the chemical bonds of multi-carbon products [28].

The low efficiency of biocathodes seriously hinders the MES productivity, which is mainly because of the barriers of charge extraction and injection between the biological and abiotic interfaces of the biological and electronic systems, namely the low charge transfer efficiency across the biological-abiotic interfaces, presenting an important obstacle to the efficient integration of biological and electronic systems [29]. Therefore, the key to MES optimization is to enhance the electron exchange on the cathode surface. At present, there has been a great improvement in understanding how organisms transfer electrons to electrodes, but the mechanism of electron transfer from the electrode to the microbe is still unclear. Although the improved method for biomaterials may still be experiential to a large extent, it works. At present, low-cost MES cathode materials mainly include carbon cloth, carbon paper, carbon felt, stone mill rod, glass carbon rod, and other carbon materials [30-35]. However, when a conventional electrode material is used as the biological electrode, its poor compatibility with organisms and small specific surface area are not conducive to full attachment of microorganisms and charge transfer at a high efficiency. The three-dimensional nanostructure of the highly conductive nano-reticulated glass carbon (Nano Web-RVC) electrode enhances the current density of the MES system. Its layered pores in this unique electrode structure can support a large number of microorganisms and facilitate mass transfer [36]. In addition, the material is inexpensive and easy to be popularized on a large scale. Besides, a novel conductive microbial nanowire electrode can promote the long-distance transfer of extracellular electrons and increase the conductivity [37]. The conductive filaments can also be used to cultivate microbial strains with a better electrical conductivity. Therefore, study of the interaction between bacteria and nanostructures may improve the MES systems that are dependent on extracellular electron exchange to obtain controllable interfaces between biological and abiotic components [38]. Silicon nanowire arrays ensure a good interaction between nanostructures and cell units. Silicon nanowire arrays with a high specific surface area can promote the reduction of $\mathrm{CO}_{2}$ and improve the performances of typical low-density microbial catalysts [38,39]. Surface modification of carbon materials by physical or chemical methods can also improve the performances of electrode materials [30].

In addition to direct utilization of external power, it is also possible to use the electricity generated via reverse electrodialysis from the green and sustainable salinity gradient energy as the driving force of MES to achieve efficient $\mathrm{CO}_{2}$ bioconversion $[40,41]$. It has been reported that a microbial reverse-electrodialysis electrolysis cell (MREC) can help realize this technology [42]. The salinity gradient is rich in energy and exists in various environments, such as seawater and river water; high/low salinity is produced by wastewater treatment. Therefore, the system can not only make use of wastewater to generate electricity, but also purify wastewater. However, this kind of energy has not yet been effectively captured and stored, and access to this energy requires the development of an effective energy conversion technology. This new technology can produce biofuels and treat wastewater at the same time, which reduces the sewage treatment cost, increases power generation, and also provides a potential technology platform for the collection and storage of salinity gradient energy and $\mathrm{CO}_{2}$ emission reduction.

\subsection{Photosynthetic biohybrid systems (PBSs)}

A PBS is a novel photo-driven device composed of bacteria or enzymes that are immobilized on inorganic semiconductor photocatalysts; it combines high-efficiency inorganic photocatalysts with enzyme catalysts or cellular organisms [20]. The efficiency of selective fixation of $\mathrm{CO}_{2}$ is close to or higher than that of natural photosynthesis or chemical catalysis $[24,43]$. Although the light absorption efficiency of inorganic semiconductors is higher than that of natural photosynthesis, these artificial photocatalysts do not display the high selectivity, low energy consumption, self-replicating, and self-healing properties of natural catalysts. In addition, the incredible biosynthetic ability can be used to not only reduce $\mathrm{CO}_{2}$ but also obtain the target products in a cost-effective and highly selective manner under mild conditions and to synthesize long-chain hydrocarbons on a large scale.

The possible structure of PBSs is shown in Fig. 2. A PBS utilizes the light-capturing performance of semiconductors to obtain photogenerated electron-hole pairs that decompose water into hydrogen and oxygen and then convert $\mathrm{CO}_{2}$ into value-added chemicals via the metabolic pathway in organisms to obtain organic acids and methane [44-47]. It can also be considered as a MES reactor that is powered by solar energy, or a modified MES electrode that directly captures light energy, thus effectively functioning as an artificial photosynthesis device that exhibits a higher solar energy efficiency than natural photosynthesis [48]. Some of these systems have been demonstrated in recent studies, and many methods have been provided to realize this concept. The high product selectivity also proves the effectiveness of the combination of biological $\mathrm{CO}_{2}$ reduction and inorganic light capture technology. Silicon nanowires, $n$ - $\mathrm{TiO}_{2}$ nanowire/FTO, $n^{+} / p$-Si, $p$-InP, metal sulfide/oxide nanoparticles (mainly $\mathrm{CdS}$ and $\mathrm{TiO}_{2}$ ), etc. have been reported as light-capturing devices for inorganic biological

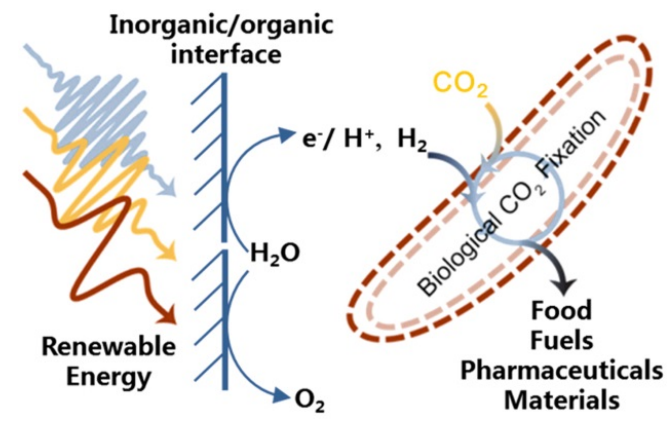

Fig. 2. Scheme of a photosynthetic biohybrid system [20]. 
hybrid systems.

PBSs are still in the early stage of development. In spite of the possibility of achieving higher solar conversion efficiencies (10\% to $20 \%$ ), several technical parameters still need to be improved, and there is still a long way to go before they can be widely implemented [49]. One of the main challenges is the selection of compatible optical capturing systems and efficient biological carbon sequestration units, as well as the seamless integration of biological and non-biological components. In other words, it is still a challenge to overcome the charge transfer barrier at the cross-biological and abiotic interfaces (mentioned in section 2.1). At this point, semiconductor electrodes with high specific surface areas, such as semiconductor silicon nanowire arrays, are ideal for obtaining high current densities under illumination [30]. In the future, new electrode materials with good electron active surfaces, low overpotentials, high specific surface areas, good biocompatibilities, and high electron transfer efficiencies need to be developed. The cost of the material needs to be considered as well. At present, electrode materials displaying the performance described above are scarce, therefore, it is imperative to reform and develop new electrode materials.

\subsection{PSII composite system}

The PSII composite system is one of the most recently proposed artificial photochemical systems that consists of natural PSII and artificial photocatalysts. Alternatively, PSII is used to modify the MES electrode to facilitate the reduction of $\mathrm{CO}_{2}$ in an artificial photochemical system [50,112]. Compared with that of PBSs, the biological enzyme of the PSII complex system is PSII. The PSII complex system can reproduce the biological characteristics of PSII, such as the excellent light collection ability. PSII can efficiently capture the energy of the visible solar spectrum across all wavelengths, which can be used to drive the decomposition of water to obtain hydrogen equivalent, which is also a unique advantage, compared with an inorganic photocatalyst.

PSII is a photoactive complex located on thylakoid membrane (TK) in green plants, cyanobacteria, and microalgae [51,52]. It can convert solar energy into chemical fuels and provide the materials and energy for almost all living creatures, including humans. The water-cleavage reaction is the origin of the whole photosynthesis process. The information found regarding the structural determination of PSII has a significant impact on the design of artificial catalytic systems that utilize solar energy to release hydrogen equivalent from water. $\mathrm{Mn}_{4} \mathrm{Ca}$ clusters in PSII are the only biocatalysts in nature that can use solar energy to oxidize water efficiently and safely and release oxygen, "high energy" electrons, and protons. It can be used in visible-light-driven water photolysis. The resulting hydrogen can be used directly as an energy source or used in photosynthesis to reduce $\mathrm{CO}_{2}$ into other fuels, such as methane. It is considered to be the best hope of developing new technologies that convert solar radiation into usable energy sources [4,50].

Some studies on visible-light-driven hydrogen production of PSII have been reported. Further, artificial photochemical sys- tems have been established to simulate the hydrogen production of the active centers in PSII. These works are of significance in further obtaining or optimizing the PSII composite system to reduce $\mathrm{CO}_{2}$ [50,53-55]. Fig. 3 illustrates the charge separation in PSII, the direction of electron flow, and the water cracking reaction and the final $\mathrm{CO}_{2}$ reduction reaction. In PSII, the light energy captured by the light-harvesting complex is rapidly funneled into the chlorophylls bound in D1/D2 subunits, resulting in charge separation and a series of electron transfers that lead to $\mathrm{Q}_{\mathrm{B}}$ cofactor. The evolution of $\mathrm{O}_{2}$ and proton $\left(\mathrm{H}^{+}\right)$occurs on $\mathrm{Mn}_{4} \mathrm{CaO}_{5}$ clusters due to water oxidation. $\mathrm{CO}_{2}$ may bind to the hydrogen equivalent released from PSII and then be reduced by inorganic catalysts, enzymes, and microorganisms to formic acid, methanol, and other chemicals [42].

There has been a lot of research on photovoltaic conversion systems assembled on electrodes using PSII, and some initial progress has been made. However, studies on $\mathrm{CO}_{2}$ reduction are still very limited. In addition, in vitro purified PSII will result in irreversible photodamage under illumination, which renders it highly unstable. The long-term anti-light stability of PSII on the electrode is a serious problem affecting the use of photovoltaic converters [56].

\subsection{Metabolic engineering}

Metabolic engineering is an applied discipline in which cellular metabolic pathways are reasonably designed according to cellular metabolic networks, and molecular biological means (such as recombinant DNA technology) are used to design and regulate the existing metabolic networks and expression regulatory networks in organisms purposefully [57-59]. In order to achieve more efficient biochemical transformations, energy transfer, and accumulation of the target products, analysis of the metabolic function of modified organisms is one of the core technologies of metabolic engineering. At present, metabolic engineering has been widely used in photosynthetic biological carbon sequestration to further optimize the resource utilization of $\mathrm{CO}_{2}$ to biomass or other organic compounds.

Photosynthetic autotrophic microalgae with $\mathrm{CO}_{2}$ fixation

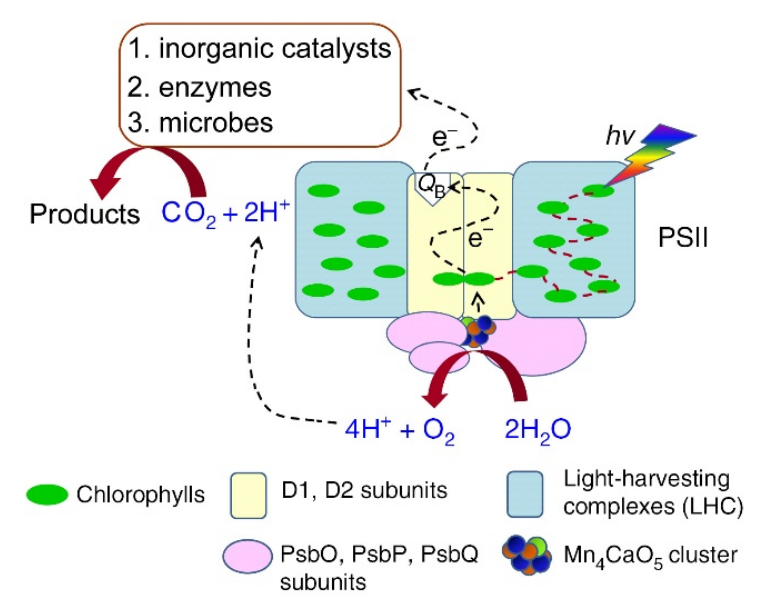

Fig. 3. Scheme of a PSII-catalyst hybrid system for solar-powered $\mathrm{CO}_{2}$ fixation [50]. 
capacity can be grown on a large scale on non-cultivated lands. Microalgae usually exhibit a higher photosynthetic efficiency than other biomass such as trees. Microalgae biotechnology, especially microalgae bioenergy, has emerged as a hot research topic at home and abroad in recent years. Sustainable energy production in the future could be achieved through a large number of photoautotrophic microorganisms [60,61]. Researchers used metabolic engineered autotrophic organisms (such as cyanobacteria) or exotic organisms (such as Escherichia coli; E. coli) to introduce reaction pathways for target chemicals into the body through metabolic engineering and eventually synthesize fuels and chemicals from $\mathrm{CO}_{2}[62,63]$. The relatively high yield of ethanol, which can be of the order of grams per liter, shows the potential of bio-carbon sequestration [64]. It is also possible to utilize the carbon sequestration pathway in organisms to construct an effective in vitro system that can transform $\mathrm{CO}_{2}$ into value-added chemicals [65].

Low energy efficiency and low carbon sequestration rate are two bottlenecks of natural photosynthesis. They are also the major challenges in basic and applied research [66]. The mismatch between the light reaction and dark reaction energies is one of the key factors limiting the photosynthesis energy efficiency and carbon sequestration rate $[67,68]$. The synthesis of isopropanol, which consumes additional NADPH in cyanobacteria, can balance the reduction power of the biological system. Thus, the photosynthetic efficiency of cyanobacteria can be greatly increased, and the growth rate and biomass of cyanobacteria can also be significantly increased [69,70]. In addition, the carbon fixation activity of microalgae can also be enhanced by regulating the RuBisCO activator (ribulose-1,5-diphosphate carboxylase) of oil-producing microalgae, thus greatly increasing the biomass and oil yield of microalgae [71].

E. coli has emerged as one of the most important model strains for studying artificial carbon sequestration in recent years. The Calvin carbon fixation cycle was successfully constructed in E. coli to realize the synthesis of sugars and other biomass, which is required for the growing demand due to $\mathrm{CO}_{2}$ $[72,73]$. RuBisCO, the key enzyme of photosynthetic carbon fixation in E. coli, will be helpful in improving the efficiency of carbon sequestration if it can be modified by mutation or other ways and lays the foundation for the increase in the grain yield $[74,75]$.

By studying metabolic engineering, raising awareness, designing and transforming the ability of the cell to metabolize $\mathrm{CO}_{2}$, a carbon sequestration pathway with low energy consumption and high efficiency can be obtained, and the biological carbon fixation industry will technologically progress, which is an important development in this field.

\section{Artificial biosynthesis of various compounds}

\subsection{C1 compounds}

The most common $\mathrm{C}_{1}$ compounds synthesized by MES are carbon monoxide, methane, formic acid, and a small amount of methanol. It is usually produced by the conversion of $\mathrm{CO}_{2}$ from methanogenic cultures and some targeted dehydrogenase
Table 2

Reduction routes and the corresponding theoretical potentials of $\mathrm{C}_{1}$ compounds synthesized by $\mathrm{CO}_{2}$.

\begin{tabular}{lcc}
\hline Reduction route & $\begin{array}{c}\text { Theoretical potential } \\
E^{0}(\mathrm{~V} \text { vs. NHE })\end{array}$ & $\begin{array}{c}\text { Series } \\
\text { number }\end{array}$ \\
\hline $\mathrm{CO}_{2}+\mathrm{e}^{-}=\mathrm{CO}_{2}{ }^{-}$ & -1.90 & $(1)$ \\
$\mathrm{CO}_{2}+2 \mathrm{e}^{-}+2 \mathrm{H}^{+}=\mathrm{CO}+\mathrm{H}_{2} \mathrm{O}$ & -0.53 & $(2)$ \\
$\mathrm{CO}_{2}+2 \mathrm{e}^{-}+2 \mathrm{H}^{+}=\mathrm{HCOOH}$ & -0.61 & $(3)$ \\
$\mathrm{CO}_{2}+4 \mathrm{e}^{-}+4 \mathrm{H}^{+}=\mathrm{H}_{2} \mathrm{CO}+\mathrm{H}_{2} \mathrm{O}$ & -0.48 & $(4)$ \\
$\mathrm{CO}_{2}+6 \mathrm{e}^{-}+6 \mathrm{H}^{+}=\mathrm{CH}_{3} \mathrm{OH}+\mathrm{H}_{2} \mathrm{O}$ & -0.38 & $(5)$ \\
$\mathrm{CO}_{2}+8 \mathrm{e}^{-}+8 \mathrm{H}^{+}=\mathrm{CH}_{4}+2 \mathrm{H}_{2} \mathrm{O}$ & -0.24 & $(6)$ \\
\hline
\end{tabular}

[76,77]. Equations (1)-(6) in Table 2 show the possible reduction routes and the corresponding theoretical potentials for the synthesis of $\mathrm{C}_{1}$ compounds by $\mathrm{CO}_{2}$ (in aqueous solutions with $\mathrm{pH}=7$ ) [78-81].

In most research, the formations of $\mathrm{C}_{1}$ products are based on reductive coenzymes, such as $\mathrm{NADH}$, which provide the electrons and hydrogen equivalent. In the presence of three dehydrogenases, namely, formate dehydrogenase (FDH), formaldehyde dehydrogenase (ALDH), and alcohol dehydrogenase $(\mathrm{ADH})$, for every two-electron reduction step of $\mathrm{CO}_{2}$, one $\mathrm{NADH}$ molecule is oxidized to $\mathrm{NAD}^{+}$in a three-step cascade. However, this irreversible oxidation of NADH is expensive to realize because of the high cost of synthesis and regeneration, which limits the application of enzymes in the reduction of $\mathrm{CO}_{2}$ [82-84]. Therefore, a proper replacement for coenzymes is quite necessary, especially direct injection of electrons into the enzyme, which has high application value [85].

The general formation mechanisms of the $\mathrm{C}_{1}$ products of $\mathrm{CO}_{2}$ artificial bioconversion process are first summarized. Carbon monoxide dehydrogenase (CODH) plays a key role in $\mathrm{CO}$ formation from $\mathrm{CO}_{2}$, which is reduced on the nickel- and iron-containing active sites of CODH [86]. At reducing potentials, $\mathrm{CO}_{2}$ acts as a bridging ligand between the nickel and the dangling iron atom to form a square planar arrangement around the nickel; then, a $\mathrm{OH}$ unit forms on the iron and $\mathrm{CO}$ species may be generated on the nickel sites. There are two mechanisms for methane production by microbial reduction of $\mathrm{CO}_{2}$ : (1) the $\mathrm{H}_{2}$ produced on the cathode surface of MES is utilized by the hydrophilic methanogenic bacteria attached to the surface of the cathode to produce methane by binding with $\mathrm{CO}_{2}$; (2) the cathode-functional microorganism can directly obtain the electron from the cathode surface to reduce $\mathrm{CO}_{2}$ to methane [86-88]. In the presence of three dehydrogenases, including formate dehydrogenase, formaldehyde dehydrogenase, and alcohol dehydrogenase, for every two-electron reduction step of $\mathrm{CO}_{2}$, one $\mathrm{NADH}$ molecule is oxidized to $\mathrm{NAD}^{+}$in a three-step cascade, as shown in Fig. 4 [89].

\subsubsection{Carbon monoxide}

$\mathrm{CO}$ is the raw material of various synthetic processes and

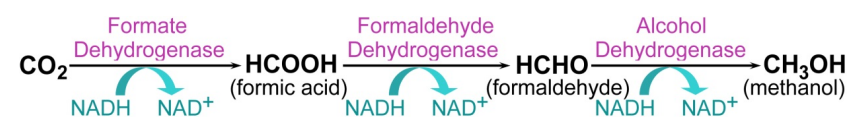

Fig. 4. General reduction mechanisms of $\mathrm{CO}_{2}$ artificial bioconversion process [89]. 
can be easily converted into liquid fuels such as methanol. Woolerton et al. [90] built a PBS that reduced $\mathrm{CO}_{2}$ to $\mathrm{CO}$ under visible light irradiation. The system used $\mathrm{TiO}_{2}$ nanoparticles modified by CODH. The researchers utilized polypyridine ruthenium, which is sensitive to visible light, to reduce the $\mathrm{CO}_{2}$ overpotential. The principles are shown in Fig. 5A. Upon excitation with visible light, RuP injects electrons into the conduction band of $\mathrm{TiO}_{2}$. These electrons can then enter $\mathrm{CODH}$ through the D-cluster and are transferred through a second [4Fe-4S] cluster to the active site, where $\mathrm{CO}_{2}$ is reduced to $\mathrm{CO}$ by enzymatic action through a two-electron reduction pathway. The measured turnover rate was around 0.14 mol CO produced (mol $\mathrm{CODH})^{-1} \mathrm{~s}^{-1}$. The semiconductor acts as a scaffold for enzyme and dye molecules: experiments in which $\mathrm{TiO}_{2}$ was omitted yielded no detectable CO. Secondly, the conduction band maintains the energy of the photoinjected electrons above a minimum potential threshold, which is sufficient for $\mathrm{CO}_{2}$ reduction by CODH. Fig. 5B presents the effect of other semiconductor materials on the production of $\mathrm{CO}$ in the system. It was found that the combination of a photosensitizer with $\mathrm{ZnO}$ was poor: only around $60 \%$ of the $56 \mathrm{nmol}$ RuP added was bound to $\mathrm{ZnO}$ after 20 min adsorption period, compared with that of almost $100 \%$ for $\mathrm{TiO}_{2}$. They used $o$-phosphorylethanolamine (OPEA) to modify the surface of $\mathrm{TiO}_{2}$. As shown in Fig. 5C, rather than obtaining the desired effect, the modified layer decreased the rate of catalysis; this is (at least in part) due to the lower uptake of an enzyme when OPEA is added. The two-electron pathway of the highly efficient and specific $\mathrm{CO}_{2}$ reduction model system can avoid the thermodynamic barrier involved in the single-electron activation pathway and provides a lot of information and constructive insights into solar-driven reduction of $\mathrm{CO}_{2}$ emissions [91].

\subsubsection{Methane}

Methanogens can reduce $\mathrm{CO}_{2}$ to methane with $\mathrm{H}_{2}$ [92]. Methane is a good fuel that can be favorably separated because of its low solubility. The direct conversion of $\mathrm{CO}_{2}$ to $\mathrm{CH}_{4}$ by using synthetic catalysts is still a huge challenge because of its high overpotential and low $\mathrm{CH}_{4} / \mathrm{H}_{2}$ selectivity. The Faraday efficiencies of the direct electrocatalytic methanogenic conversion of two kinds of $\mathrm{CO}_{2}$ with high activity and selectivity to $\mathrm{CH}_{4}$ were $61 \%$ and $76 \%$, respectively, but the overpotentials $(\eta)$ required were $1.28 \mathrm{~V}$ and $1.52 \mathrm{~V}[93,94]$. Cheng et al. [95] reported for the first time that $\mathrm{CO}_{2}$ can be reduced to methane by Methanobacterium palustre under the condition that the cathodic potential is less than $0.7 \mathrm{~V}(v s . \mathrm{Ag} / \mathrm{AgCl})$. The continuous yield of me-

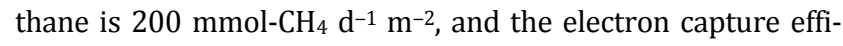
ciency $96 \%$.

Nichols et al. [96] used Methanosarcina barkeri (M. barkeri) biocatalyst to reduce $\mathrm{CO}_{2}$ to $\mathrm{CH}_{4}$. Fig. $6 \mathrm{~A}$ shows a general schematic of the gastight, two-compartment electrochemical cell that was specially designed for batch-mode electrolysis and subsequent headspace analysis by gas chromatography. The cell employs platinum or an earth-abundant substitute, such as $\alpha$-NiS, as the biocompatible hydrogen evolution reaction (HER) electrocatalyst and M. barkeri as the biocatalyst for $\mathrm{CO}_{2}$ fixation. In Fig. 6B, the variation in the applied current from $1 \mathrm{~mA}$ to 7.5 $\mathrm{mA}$ shows that the $\mathrm{CH}_{4}$ generation is proportional to the applied current, suggesting that the system is operating in a hydrogen-limited regime. When the applied current is $2.5 \mathrm{~mA}$, the system displays high Faradaic efficiencies (of up to 86\%) and a low overpotential $(\eta=360 \mathrm{mV})$. A slight decrease in the Faradaic efficiency is observed at higher current densities. The researchers then replaced the expensive platinum with nano- $\alpha-\mathrm{NiS}$, the electrocatalytic performance of which is presented in Fig. 6C and Fig. 6D. When the current is increased to $7.5 \mathrm{~mA}$, the results obtained from experiments using $\alpha-\mathrm{NiS} / \mathrm{C}$ are virtually indistinguishable from those obtained with platinum in terms of the daily and cumulative amounts of methane generated; $4.24 \mathrm{mmol}$ of $\mathrm{CH}_{4}$ is produced over 7 days, with an average Faradaic efficiency of $74 \%$. In addition, photoactive cathodes were prepared by sputtering a thin layer of nickel-molybdenum alloy atop $\mathrm{TiO}_{2}$-passivated $\mathrm{n}^{+} / p$-Si. At $2.5 \mathrm{~mA}$ and only $175 \mathrm{mV}$ overpotential, biological galvanostatic electrolysis generated $0.692 \mathrm{mmol} \mathrm{CH}_{4}$, with the Faradaic efficiency being $82 \%$, which allowed more methane to be produced for a certain amount of electricity. On the other hand, for the combination of $\mathrm{n}-\mathrm{TiO}_{2}$ photoanode and $p$-InP photocathode, $\mathrm{CO}_{2}$ can be converted into $\mathrm{CH}_{4}$ without being driven by light.

\subsubsection{Formic acid}

Song et al. [97] reported that two acetogenic bacteria, Moorella heatacetica $(M t)$ and Foricoaceticum $(C f)$, can effectively convert $\mathrm{CO}_{2}$ to formic acid below $0.58 \mathrm{~V}$, with the current efficiencies being $80 \%$ and $100 \%$, respectively. Lee et al. [98] reported the highly selective reduction of $\mathrm{CO}_{2}$ to formate on a
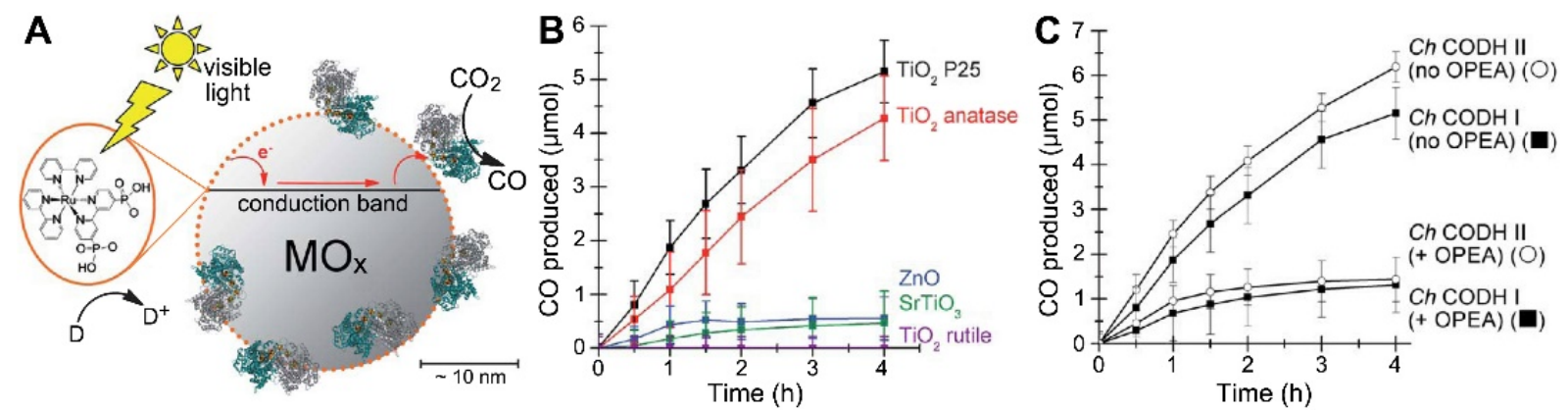

Fig. 5. (A) Cartoon representation of $\mathrm{CO}_{2}$ reduction at an enzyme-modified metal oxide nanoparticle sensitized with a ruthenium dye; (B) CO production for $5 \mathrm{~mL}$ suspensions of various semiconductors modified with $\mathrm{Ch}$ CODH I $(2.56 \mathrm{nmol})$ and RuP ( $56 \mathrm{nmol})$; (C) Effect of OPEA modification of TiO 2 on $\mathrm{CO}$ production [90]. 

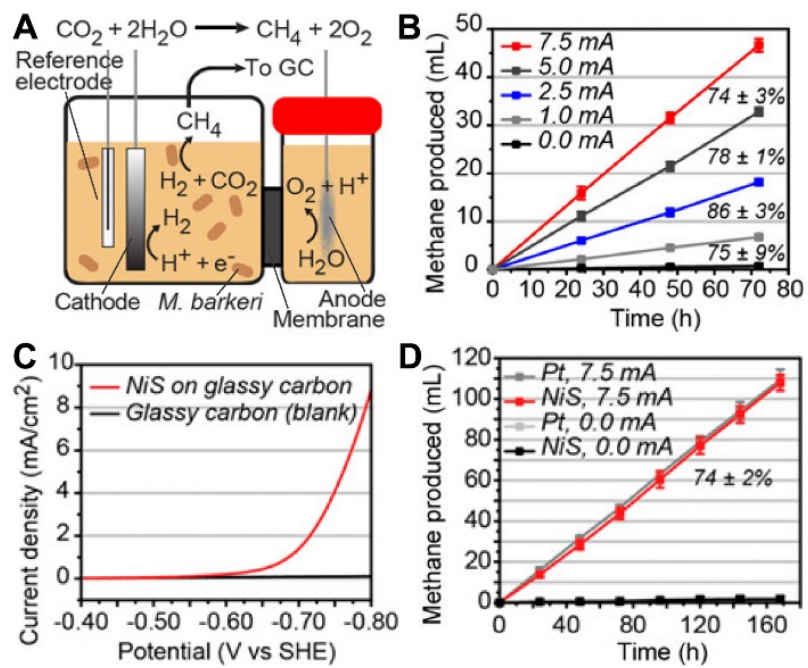

Fig. 6. (A) Electrocatalytic reduction of carbon dioxide to methane on a hybrid platinum/M. barkeri platform; (B) Cumulative methane generation and the associated average Faradaic efficiencies obtained at various currents; (C) Polarization curve; (D) Methane generation and the associated average Faradaic efficiency [96].

tightly integrated bioelectrode. They used the multifunctional polydopamine (PDA) membrane with biocompatibility and good charge transferability as the substrate for the immobilized enzymes NADH (C, NADH) and FDH (E, FDH), which acted as the electron mediator and reaction catalyst, respectively [99], as shown in Fig. 7A. This bio-hybrid system with nanometer thickness not only promoted electron transfer but also kept the enzyme stable on the electrode for a long time (for about two weeks) [100]. In Fig. 7B, the much lower capacitive current of the EC-PDA layer in comparison to that of PDA indicated that a denser and/or thinner film was formed when EC was incorporated into the PDA film $[99,101]$. In addition, a sustainable energy conversion system composed of nano-porous $\mathrm{COPI} / \mathrm{BiVO}_{4}$ photoanode and EC-PDA biocathode without an external bias was designed [102,103]. Fig. 7C shows

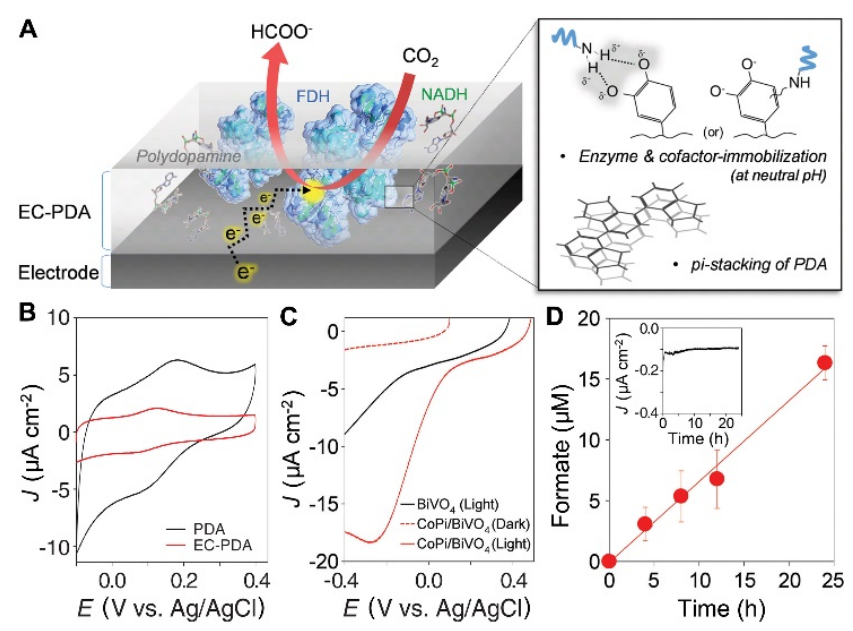

Fig. 7. (A) Schematic illustration of the $3 D$ structure and the proposed formation mechanism of EC-PDA thin film-coated biocathode; (B) Cyclic voltammograms of PDA and EC-PDA coated GCE; (C) Linear sweep voltammogram; (D) Photocatalytic formate formation from $\mathrm{CO}_{2}$ gas as a function of irradiation time [98]. the $I$ - $V$ curves of the EC-PDA double electrode structure under light and dark conditions, which can be used to estimate the difference in the open-circuit voltage between the light and dark conditions as $400 \mathrm{mV}$. The open-circuit voltage increased by $110 \mathrm{mV}$ and the short-circuit current doubled, indicating that CoPi is a good OER catalyst that can effectively reduce the kinetic overpotential of the photoanode. For long-term stability tests, the current density was monitored for $24 \mathrm{~h}$ at a constant voltage of $0 \mathrm{~V}$ ( vs. $\mathrm{CoPi} / \mathrm{BiVO}_{4}$ photoanode), and the result is displayed in Fig. 7D. The chronoamperometric current was low, but stable at $-0.1 \mu \mathrm{A} \mathrm{cm}^{-2}$, and was believed to result from the fast kinetics at the cathode and dissolution of $\mathrm{CO}_{2}$ into the aqueous solution, as revealed in the inset of Fig. 7D. The amount of formate produced increased linearly with the reaction time, and $15 \mu \mathrm{mol} \mathrm{L}-1$ formic acid was produced after $24 \mathrm{~h}$. HPLC analysis result clearly reveals that formate is the only product of light-driven $\mathrm{CO}_{2}$ reduction by EC-PDA biocathode, with the Faradaic efficiency being almost perfect at $100 \%$.

Amao et al. [104] studied the preparation of TK assembled on $\mathrm{TiO}_{2}$ thin film electrode and its photocurrent conversion function. By using PSII as the photocatalytic material for oxygen production, a composite electrode with PSII function was prepared. Oxygen evolution with PSII in $\mathrm{TK} / \mathrm{TiO}_{2}$ occurs under visible-light irradiation. Electron transfers from TK to the conduction band of $\mathrm{TiO}_{2}$, and then from $\mathrm{TK} / \mathrm{TiO}_{2}$ to the co-immobilized $\mathrm{FDH}-\mathrm{CH}_{3} \mathrm{~V}\left(\mathrm{CH}_{2}\right)_{9} \mathrm{COOH}$ cathode via the external circuit. $\mathrm{CO}_{2}$ is then reduced to formic acid by FDH at the cathode. Formic acid and oxygen are formed in the stoichiometric ratio of 2:1.

\subsubsection{Methanol}

Formic acid is the main product in most studies, with trace amounts of formaldehyde or methanol. One of the reasons is the strong equilibrium of formaldehyde on methanol hydrate $[105,106]$. Scientists often use the coenzyme NADH to produce methanol. However, there have been few attempts at reducing $\mathrm{CO}_{2}$ to methanol and few reports on methanol products. Yadav et al. [107] reported selective methanol production for the first time by visible-light-driven $\mathrm{CO}_{2}$ reduction in PBSs. In this study, IP (isatin-porphyrin) chromophore covalently binds to chemically converted graphene (CCG) to form the visible light active photocatalyst CCG-IP, as shown in Fig. 8A [108]. CCG acts as an electron storage layer to transport multiple electrons. CCG-IP exhibits efficient visible light capturing capability, providing energy for efficient regeneration of $\mathrm{NADH}$, which is an essential condition for methanol generation from $\mathrm{CO}_{2}$ [109]. Fig. 8B shows that CCG-IP linearly accumulates $38.99 \%$ of NADH within $60 \mathrm{~min}$. On the other hand, CCGCMAQSP (chemically converted graphene coupled multi-anthraquinone-substituted porphyrin) photocatalyst and IP chromophore regenerated $28.46 \%$ and $7.03 \%$ of NADH within the same time frame, respectively. However, CCG failed to regenerate any NADH. Methanol of concentration $11.21 \mu \mathrm{mol} \mathrm{L}-1$ was obtained on exposure to visible light over the subsequent $60 \mathrm{~min}$ when CCG-IP was used as the photocatalyst. On the other hand, only $5.62 \mu \mathrm{mol} \mathrm{L}-1$ of methanol was obtained upon the use of CCGCMAQSP as the photocatalyst. The experiment with IP 

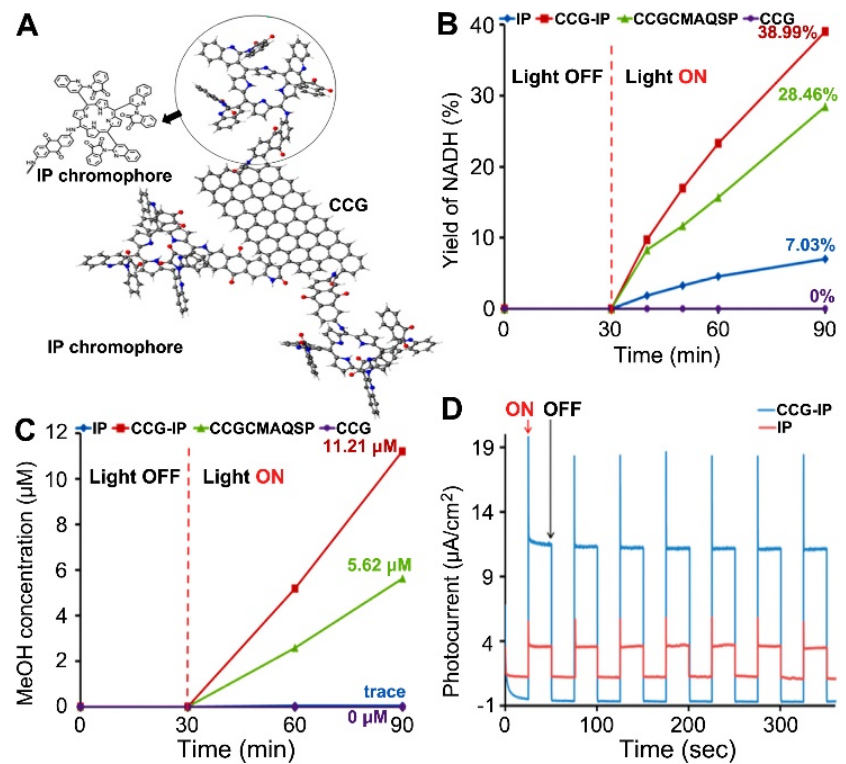

Fig. 8. (A) 3D structure of CCG-IP photocatalyst, along with the detailed chemical structure of IP chromophore; (B) Photocatalytic 1,4-NADH regeneration activity; (C) Production of methanol; (D) Photocurrent-time (I-T) profiles of FTO/IP and FTO/CCG-IP electrodes under simulated solar light illumination [107].

chromophore afforded a trace amount of methanol, which could not be quantified, while CCG failed to produce any methanol, as observed in Fig. 8C. The result of transient photocurrent study in Fig. 8D shows that the prompt photocurrent response of CCG-IP corresponds well with the ON/OFF cycles of the simulated sunlight irradiation. It indicates electron transfer from IP to CCG upon irradiation, which leads to regeneration of the enzymatically active 1,4-NADH and subsequent methanol formation [108].

Schlager et al. [89] reported a method of direct $\mathrm{CO}_{2}$ reduction by MES that involves injecting electrons directly into the electrode without the need for the expensive coenzyme NADH. FDH, ALDH, and ADH are immobilized in matrices to ensure high stability of the enzyme and high activity and reusability of the biocatalysts, as shown in Fig. 9A [110]. Fig. 9B indicates that a methanol peak appears at a residence time of $1.85 \mathrm{~min}$ after electrolysis for $4 \mathrm{~h}$. Around $0.15 \mathrm{ppm}$ of methanol is detected in the electrolysis experiment at a constant potential of $1.2 \mathrm{~V}$ ( $v s$.
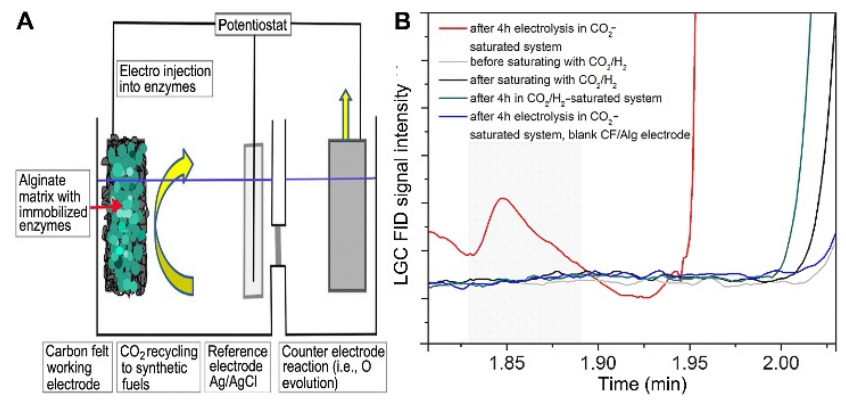

Fig. 9. (A) Representation of the electrochemical $\mathrm{CO}_{2}$ reduction process using enzymes, and electrons are injected directly into the enzymes, which are immobilized in alginate silicate hybrid gel (green) on a carbon-felt working electrode; (B) Comparison of chromatograms obtained by LGC [89].
$\mathrm{Ag} / \mathrm{AgCl}$ ), which corresponds to a Faradaic efficiency of around $10 \%$. For the samples not subjected to electrolysis, where the enzyme electrode is stored only in a saturated solution of $\mathrm{CO}_{2}$ or $\mathrm{H}_{2}$, no methanol peak can be observed. This method provides the possibility of selective reduction of $\mathrm{CO}_{2}$ emission under mild operating conditions.

Lian et al. [111] prepared a kind of photoelectric catalytic cell with self-reducible $\mathrm{CO}_{2}$ by using PSII modified photoanode. The system uses copper foam as the photoanode and p-silicon nanowires (Si-NW) as the photocathode. Under sunlight irradiation, PSII decomposes water to generate hydrogen and electrons. Electrons transfer rapidly from PSII to the $\mathrm{Cu}$ foam, and then, the Si-NW capture the electrons in an external circuit at $0.5 \mathrm{~V}$ bias. Its appropriate conductive band potential (of $0.6 \mathrm{eV}$ ) makes it easier to reduce $\mathrm{CO}_{2}$ to methanol at the photocathode.

\section{2. $C_{2}$ compounds}

Generally, the generation mechanisms of $\mathrm{C}_{2}$ products from $\mathrm{CO}_{2}$ artificial bioconversion are more complicated, and involve $\mathrm{C}-\mathrm{C}$ coupling in biological carbon sequestrations. There are carbon sequestration pathways that can directly fix $\mathrm{CO}_{2}$. They are Calvin cycle, (CBB), reductive tricarboxylic acid cycle (rTCA), Wood-Ljungdahl pathway (W-L), and dicarboxylate/4-hydroxybutyrate cycle. The first two pathways are aerobic pathways, whereas the latter two are anaerobic pathways. The natural pathways for carbon sequestration with substrate $\mathrm{HCO}_{3}{ }^{2-}$ are as follows: 3-hydroxypropionate cycle, 3-hydroxypropionate/4-hydroxybutyrate autotrophic pathway, and dicarboxylate/4-hydroxybutyrate cycle [112].

\subsubsection{Acetic acid}

Obligate anaerobic acetogen can convert $\mathrm{H}_{2}$ and $\mathrm{CO}_{2}$ into various fuels and chemicals such as acetic acid $\left(\mathrm{CH}_{3} \mathrm{COOH}\right)$ through the efficient and energy-saving Wood-Ljungdahl pathway [100-102]. Acetic acid is the most studied $C_{2}$ product at present. Sporomusa ovata (S. ovata) is the most effective acetic acid producing strain reported so far in pure culturing $[113,114]$.

One way to improve the reduction rate of $\mathrm{CO}_{2}$ in the process of MES is to modify the cathode to improve the interaction between the microorganism and the electrode. Nie et al. [115] used graphite electrodes coated with porous nickel nanowires to increase the interface area and the interaction between the cathode surface and the bacterial biofilm. The biological reduction rate was increased by 2.3 times. They were given $540 \mathrm{mg}$ $\mathrm{L}^{-1}$ of acetic acid on day 8. A novel 3D graphene-nickel foam (G-NF) cathode has been fabricated by hydrothermal approach for the improvement of the microbially catalyzed reduction at the MES cathode. The concentration of acetic acid obtained by Song et al. [116] after 28 days of MES was $5.46 \mathrm{~g} \mathrm{~L}^{-1}$. They prepared a novel 3D G-NF cathode by hydrothermal method. The hierarchical porous G-NF cathode improved bacterial colonization and the efficiency of mass, nutrient, and proton transfer owing to its 3D composition. The graphene coating considerably increased the effective surface area for microbial adhesion, as well as the electron transfer rate of the biofilm in MES. An 
increase of 1.8 times in the volumetric acetate production rate was obtained, compared with that for untreated nickel foam.

Bian et al. [117]. used porous nickel hollow fibers (Ni-PHFs) coated on carbon nanotubes (CNTs) to form a new functional Ni-PHF/CNT with high biocompatibility. The material was used as the cathode to produce acetic acid through MES. Fig. 10A and Fig. 10B are the scanning electron microscope images obtained before and after the growth of $S$. ovata on Ni-PHF/CNT. The $\mathrm{Ni}$-PHF surface is covered with CNTs, which further improves the surface roughness and pore density of the PHFs observed in Fig. 10A. The surface of Ni-PHF/CNT exhibits a completely bacterial structure in Fig. 10B. The 11.1 times higher $\mathrm{CO}_{2}$ adsorption obtained in the case of the Ni-PHF/CNT cathode is possibly attributed to the deposited CNT layers, which show strong physical interactions with $\mathrm{CO}_{2}$ molecules $[118,119]$. In addition, improved $\mathrm{CO}_{2}$ adsorption on the Ni-PHF/CNT can be due to the large surface area and geometry of the CNTs, which exhibit different regions and sites for adsorption [120]. The HERs of Ni-PHF and Ni-PHF/CNT cathodes were characterized by linear sweep voltammetry (LSV). The LSV curve of Fig. 10C shows that when the voltage is $-1.0 \mathrm{~V}$, Ni-PHF/CNT displays a good catalytic activity towards the HER, and the current density is 1.66 times higher than that of Ni-PHF. The Tafel slopes derived from LSV data are commonly believed to be an indication of the HER catalytic properties of electrode materials [121]. In Fig. 10C, the Ni-PHF/CNT cathode exhibits 15\% lower Tafel slope (342 $\mathrm{mV} \mathrm{dec}^{-1}$ ) compared to that of Ni-PHFs (393 $\mathrm{mV} \operatorname{dec}^{-1}$ ), which suggests that Ni-PHF/CNT is a better HER catalyst. Fig. 10D shows that the rate of acetic acid production is $1.85 \mathrm{~g} \mathrm{~m}^{-2} \mathrm{~d}^{-1}$ and the Coulomb efficiency is up to $83 \%$ when $\mathrm{CO}_{2}$ is directly transported through the pores of Ni-PHF/CNT hollow fiber.

Liu et al. [44] developed a biologically compatible nanowire array to realize a PBS. The semiconductors silicon and $\mathrm{TiO}_{2}$
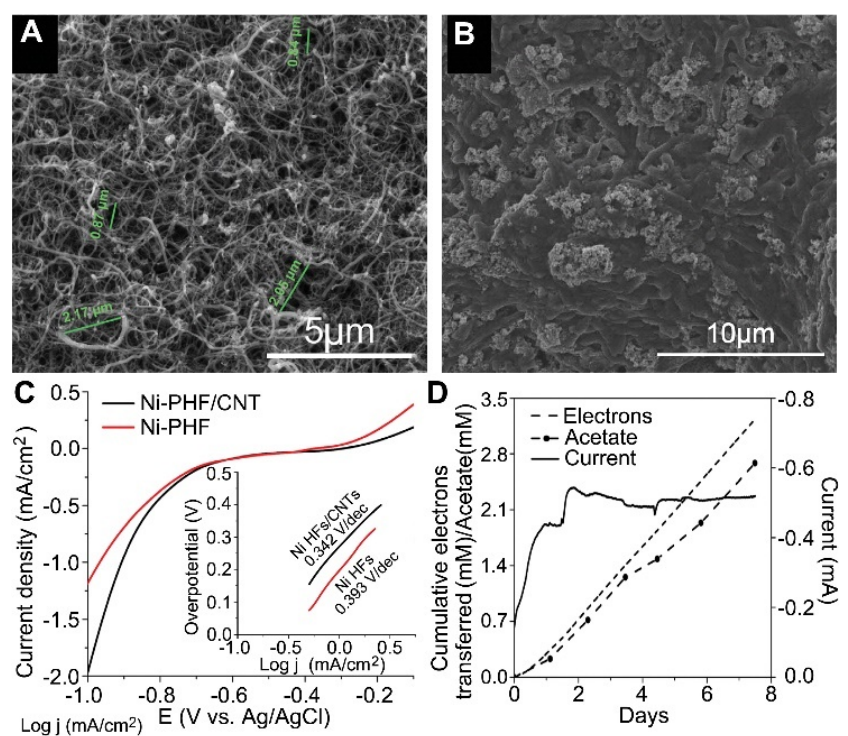

Fig. 10. (A) Scanning electron microscopy (SEM) images of $\mathrm{Ni}$-PHF/CNT cathode; (B) Ni-PHF/CNT cathode with S. ovata biofilm on the surface of the cathodes; (C) LSV curves obtained for the Ni-PHF and $\mathrm{Ni}$-PHF/CNT electrodes; (D) Electron transfer, measured acetate production, and current consumption of the Ni-PHF/CNT cathode [117]. were selected as the photocathode for hydrogen production and as the photoanode for oxygen production, and ionic conductive films were introduced between silicon nanowires and $\mathrm{TiO}_{2}$ nanowires to realize macroscopical separation of $\mathrm{H}_{2}$ and $\mathrm{O}_{2}$. In neutral $\mathrm{pH}$, only solar energy was required to feed the silicon nanowire array, and the nanowire-bacteria hybrids were capable of reducing $\mathrm{CO}_{2}$ to acetate under continuous sparging with an overpotential less than $200 \mathrm{mV}$ at $0 \mathrm{~V} v \mathrm{vs}$. reversible hydrogen electrode (RHE). Careful characterization in the form of SEM (Fig. 11A) indicates that bacteria populate quite uniformly in the array without apparent mass transport issues. The cell loading of $S$. ovata within the nanowire array is 4.4 times that observed on a planar silicon electrode. From classical electrochemical analysis of the case without solar illumination (Fig. 11B), it was observed that the nanowire-bacteria hybrids are capable of reducing $\mathrm{CO}_{2}$ to acetate under continuous sparging with $20 \% \mathrm{CO}_{2} / 80 \% \mathrm{~N}_{2}$ with an overpotential less than $200 \mathrm{mV}$ at $0 \mathrm{~V}$ vs. RHE. Additionally, the Tafel slope of bacteria-catalyzed $\mathrm{CO}_{2}$ reduction is distinctly different from that of abiotic proton reduction, implying different reaction mechanisms. The overall system produced about $0.3 \mathrm{~mA} \mathrm{~cm}^{-2}$ photocurrent under simulated sunlight (AM $1.5 \mathrm{G}, 100 \mathrm{~mW} \mathrm{~cm}^{-2}$ ) and was stable for more than $120 \mathrm{~h}$; acetic acid was steadily produced with a product selectivity (Faradaic efficiency) of $86 \%$, as shown in Fig. 11C. The acetic acid titers were ca. $1.2 \mathrm{~g} \mathrm{~L}^{-1}(20 \mathrm{mmol} \mathrm{L}-1)$ after 5 days and could reach over $6 \mathrm{~g} \mathrm{~L}^{-1}$ (ca. $100 \mathrm{mmol} \mathrm{L}^{-1}$ ) in M9-MOPS minimal medium. The resulting acetic acid can be activated to acetyl coenzyme A by genetically engineered $E$. coli, and the acetyl coenzyme A can be used as raw materials for various additional value chemicals such as $n$-butanol, polyhydroxybutyrate, and three different isoprenes [122,123].

Sakimoto et al. [124] reported the modification of non-photosynthetic heterotrophic bacteria (Moorella thermoacetica, $M t$ ) by using cadmium sulfide (CdS) nanoparticles to
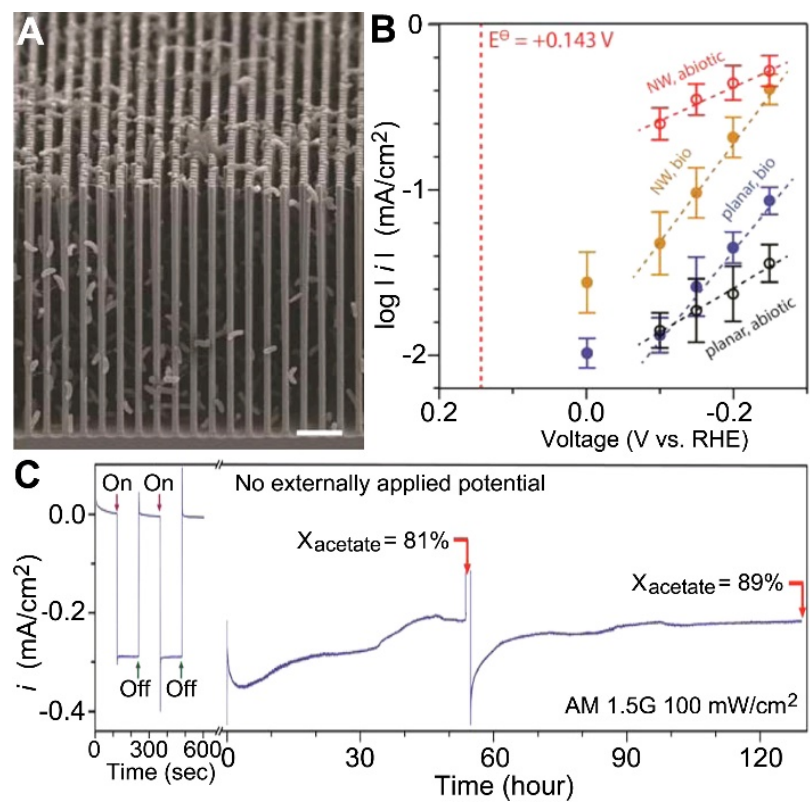

Fig. 11. (A) Cross-sectional SEM image of the 3D network in the nanowire-bacteria hybrid; (B) Tafel plots; (C) Nonzero photocurrent [44]. 
construct a new PBS [125]. The researchers designed a bionic system based on "Z-scheme" in series. In the system shown in Fig. 12A, photoreduction and photooxidation were carried out by $\mathrm{CdS}$ and $\mathrm{TiO}_{2}$ nanoparticles loaded with $\mathrm{Mn}$ ( II) phthalocyanine (MnPc), respectively. Furthermore, light of wavelengths greater than $400 \mathrm{~nm}$ was successfully absorbed with the increase in the $\mathrm{MnPc}$ content on $\mathrm{TiO}_{2}$. These two catalysts are linked by cystine/cysteine (Cyss/Cys), a biocompatible redox medium, which increases the electrical conductivity. On the cell surface, photoexcitation of the electrons released by the CdS nanoparticles produces a reduction equivalent $[\mathrm{H}]$. Then, the $\mathrm{CO}_{2}$ and $[\mathrm{H}]$ are reduced to acetic acid in the $W-L$ pathway of $M t$, which is photoreduction; photooxidation involves $\mathrm{TiO}_{2}$ nanoparticles loaded with MnPc, which restore Cyss to Cys and oxidize water. The photoinduced holes are quenched by extracellular Cys [126]. In Fig. 12B, the photosynthetic properties of the $M t-\mathrm{CdS}+\mathrm{TiO}_{2}-\mathrm{MnPc}$ tandem systems were compared with those of the control system, which produced more acetic acid. The rate of acetic acid formation tends to stabilize after about 1 day in the case of $M t$-CdS system. The acetic acid yields of $M t$-CdS and $M t$-MnPc in the control system are both below the stoichiometric limits set by Cys as a limit preparation (dotted line, Cys-free optical regeneration). MnPc-free $M t$-CdS $\mathrm{TiO}_{2}$ and CdS-free $M t+\mathrm{TiO}_{2}$-MnPc series of systems display poor performances in terms of producing acetic acid.

\subsubsection{Ethanol}

Mohanakrishna et al. [17] used five different concentrations of enriched mixed homotype acetic acid-producing bacteria as cathodic biocatalysts to perform MES for reducing $\mathrm{CO}_{2}$ into

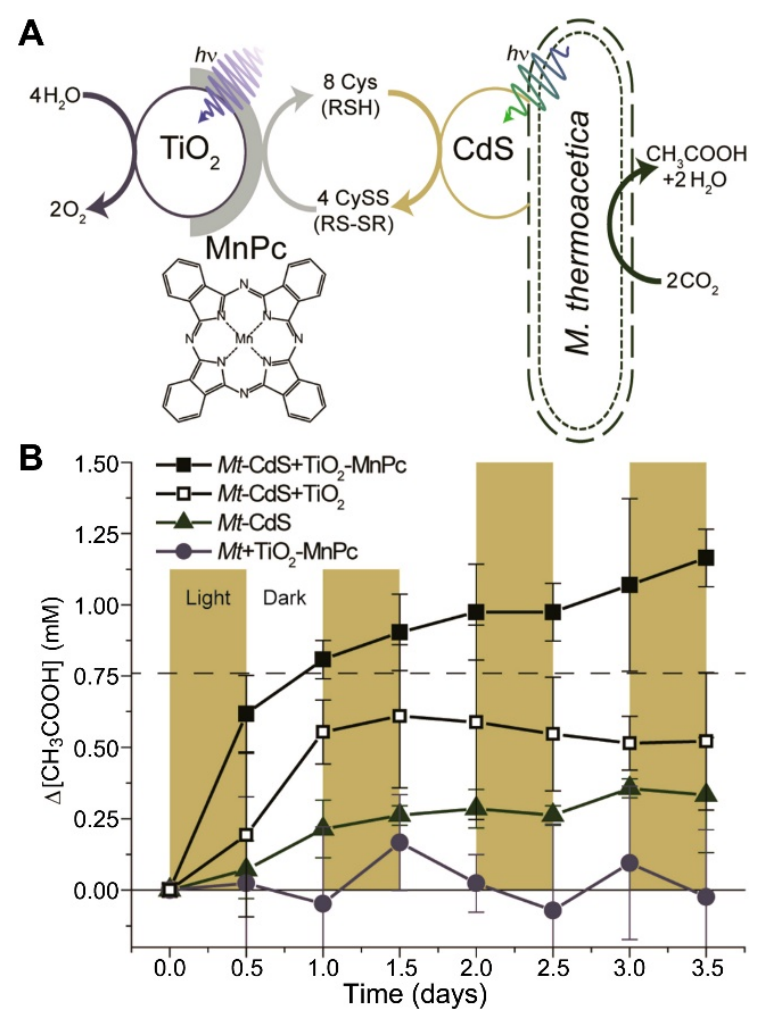

Fig. 12. (A) Schematic of the $M t-\mathrm{CdS}+\mathrm{TiO}_{2}-\mathrm{MnPc}$ tandem system; (B) Photosynthetic performance [124]. acetic acid and ethanol at a constant potential. With the increase in the carbon concentration, improvements in the acetate production rate and carbon conversion were observed. A maximum acetate production rate of $142.2 \mathrm{mg} \mathrm{L}^{-1}$ per day and a maximum carbon conversion efficiency of $84 \%$ were achieved at the $\mathrm{HCO}_{3}{ }^{-}$concentrations of $4.0 \mathrm{~g} \mathrm{~L}^{-1}$ and $2.5 \mathrm{~g} \mathrm{~L}^{-1}$. The $\mathrm{pH}$ changes caused by the interaction between $\mathrm{HCO}_{3}{ }^{-}$ (substrate) and acetate (products) can produce buffer properties at the cathode, which control the $\mathrm{pH}$ and substrate specificity during the MES process. At a higher concentration of acetic acid, the conditions for the reduction of acetic acid to ethanol can become more favorable, depending on the acidic $\mathrm{pH}$ environment. The maximum ethanol production of $65 \mathrm{mg} \mathrm{L}^{-1}$ was observed at $4.0 \mathrm{~g} \mathrm{HCO}_{3}-\mathrm{L}^{-1}$.

Hydrogen produced from water electrolysis is an important medium for the electrochemical reduction of $\mathrm{CO}_{2}$ at the cathode, and the supply of hydrogen also promotes the production of ethanol. Blanchet et al. [113] found that the acetic acid production of pure $S$. ovata culture grown under $\mathrm{H}_{2}$ and $\mathrm{CO}_{2}$ was up to $2904 \mathrm{mg} \mathrm{L}^{-1}$. About 7 days later, ethanol production began and the acetic acid production plateaued. After 10 days of cultivation, an ethanol yield as high as $1411 \mathrm{mg} \mathrm{L}^{-1}$ was obtained.

Li et al. [42] combined reverse electrodialysis technology with MES to develop a MREC for the first time. The researchers used the salinity gradient (composed of a high-concentration $\mathrm{NaCl}$ solution and a low-concentration $\mathrm{NaCl}$ solution) as the driving energy to realize the efficient biotransformation of $\mathrm{CO}_{2}$ to value-added chemicals. The concentration of acetic acid increased gradually with time, reaching $7.33 \mathrm{mM}$, as shown in Fig. 13A, and the maximum concentration of ethanol was determined to be $39.1 \mathrm{mg} \mathrm{L}^{-1}$, as shown in Fig. 13B. No acetic acid or ethanol was produced when $S$. ovata and the salinity gradient were not inoculated. In Fig. 13C and Fig. 13D, the injection of $S$. ovata enhances the current at the cathode, and the mechanism remains to be clarified. The cathodic potential stabilized at $0.680 \mathrm{~V}$ after 5.5 days, then, the current began to decrease,
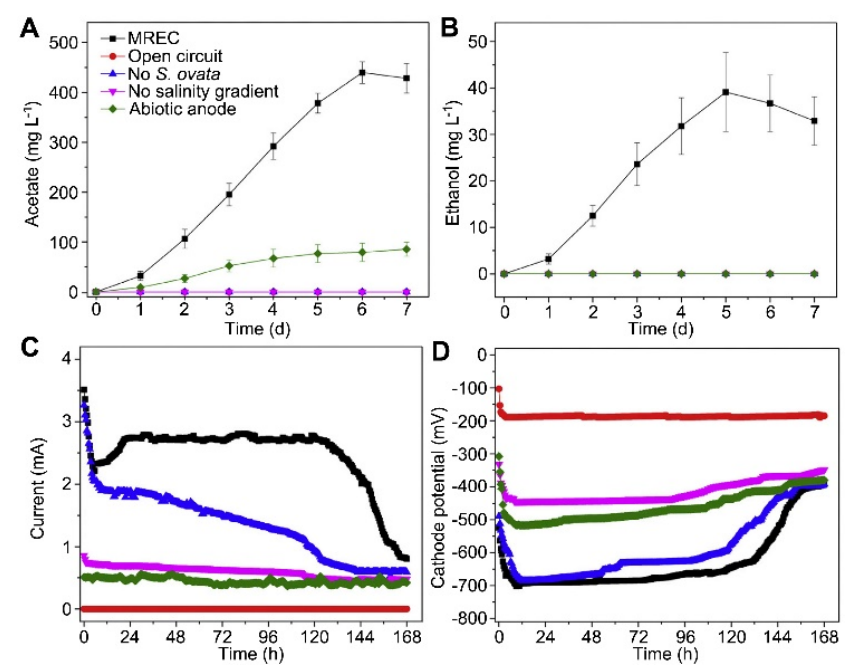

Fig. 13. Feasibility of MREC on the conversion of $\mathrm{CO}_{2}$ to acetate and ethanol [42]. The concentrations of (A) acetate and (B) ethanol as functions of time; (C) The current; (D) The cathodic potential during the $\mathrm{CO}_{2}$ reduction process. 
and the concentrations of acetic acid and ethanol reached the highest levels on the 6th day, as shown in Fig. 13A and Fig. 13B. After the reaction, the removal rate of COD and the Coulomb efficiency in the anode chamber reached $85.26 \%$ and $37.82 \%$, respectively. This low Coulombic efficiency is possibly because the COD of wastewater could also be removed by the non-exoelectrogenic microorganisms present in wastewater. These results indicate that MERC is an alternative method of $\mathrm{CO}_{2}$ conversion into value-added chemicals and wastewater treatment.

Biogenetic engineering is an efficient bioethanol production technology that combines solar energy conversion, carbon sequestration, and ethanol production [127]. Deng et al. [128] proved that ethanol can be produced from absorbed $\mathrm{CO}_{2}$ by photosynthesis through metabolic engineering. Synechocystis sp. PCC 6803 is a heterotrophic cyanobacterium and is the first fully sequenced and annotated photosynthetic autotrophic organism [129]. Dexter et al. [130] reported the photoautotrophic Synechocystis sp. PCC 6803 that converted $\mathrm{CO}_{2}$ into bioethanol. The ethanol-producing pyruvate decarboxylase of Zymomonas mobilis and ADH II genes were integrated into the chromosome of Synechocystis sp. PCC 6803 by using a double homologous recombination system. The ethanol concentration of the system reached $12 \mathrm{mM}$. Gao et al. [131]. used Synechocystis sp. PCC 6803 to increase the yield of ethanol to $5.50 \mathrm{~g}$ $\mathrm{L}^{-1}$. In 2017, Kopka et al. [132] systematically analyzed another ethanol-producing cyanobacterium Synechococcus sp. PCC 7002. They established an additional biosynthesis pathway in cyanobacteria host cells. The new ethanol-producing cyanobacteria engineering strain accumulated $0.25 \%(v / v)$ ethanol after 30 days of culturing.

\section{3. $C_{2+}$ compounds}

The mechanisms of the formation of $\mathrm{C}_{2+}$ products from $\mathrm{CO}_{2}$ artificial bioconversion are similar to those of the $\mathrm{C}_{2}$ compounds, though much more complicated steps are involved. The key step in these carbon sequestration pathways that catalyze $\mathrm{CO}_{2}$ fixation to produce $\mathrm{C}_{2}+$ compounds is the Calvin cycle. $\mathrm{CO}_{2}$ and $\mathrm{H}_{2}$ can be immobilized by the Calvin cycle to produce a variety of $\mathrm{C}_{3+}$ products, such as poly(3-hydroxybutyrate) (PHB) and $\mathrm{C}_{3}-\mathrm{C}_{5}$ alcohols. The Calvin cycle could even be combined with metabolic engineering to design reaction pathways for specific products such as isopropanol.

The aerobic microorganism $R$. eutropha without an organic growth substrate can use $\mathrm{H}_{2}$ and $\mathrm{CO}_{2}$ as its sole energy and carbon source and immobilize $\mathrm{CO}_{2}$ through Calvin cycle, which is the main carbon sequestration pathway of the biosphere $[133,134]$. The ability of the OER at low overpotentials has been realized in the neutral $\mathrm{pH}$ range (6-8) with the development of cobalt phosphate (CoPi) catalyst. The OER catalyst shares many properties with the oxygen production catalyst in PSII, including its structure, self-assembling ability, self-repairing ability, low toxicity to bacteria, and good biocompatibility. More importantly, this kind of catalyst would not produce reactive oxygen species (ROS), resulting in a significant reduction in the voltage for water decomposition; the en- ergy conversion efficiency is thus improved [19,135-137]. The resulting hydrogen can bound to $\mathrm{CO}_{2}$ when the CoPi catalyst is coupled with the HER catalyst, which lays the foundation for the production of liquid and solid fuels [138].

\subsection{1. $P H B$}

Chong et al. [9] recently developed an efficient PBS consisting of cobalt phosphate | cobalt-phosphorus | Ralstonia eutropha (CoPi | Co-P | R. eutropha). At a low driving voltage, CoPi can decompose water into molecular hydrogen and oxygen and can store more than half of the energy of the input system in the form of $\mathrm{CO}_{2}$ reduction product. The products are PHB and $\mathrm{C}_{3}-\mathrm{C}_{5}$ alcohols. Entries 1, 2, 3, and 5 show that $\eta_{\text {elec }}$ increases with decreasing $E_{\text {appl }}$ below $100 \% \mathrm{CO}_{2}$ until $E_{\text {appl }}<2.0 \mathrm{~V}$, as shown in Fig. 14A. Below Eappl $=2.0 \mathrm{~V}$ (entry 8), a higher salt concentration (108 entries for phosphate buffer) is required to facilitate mass transport and the attendant current. However, high salt concentrations are undesirable for R. eutropha metabolism. The results show that at the optimal phosphate concentration of $36 \mathrm{mM}$ and $E_{\mathrm{appl}}=2.0 \mathrm{~V}$, the highest biomass yield was $54 \%$ (entry 5 ) for a duration of 6 days. This biomass yield is equivalent to assimilating ca. $4.1 \mathrm{~mol}(180 \mathrm{~g})$ of $\mathrm{CO}_{2}$ with 1 $\mathrm{kWh}$ of electricity. Enlarging the batch reactor volume by a factor of 10 did not affect the efficiency (entries 4 and 6), indicating that the system is scalable and that the reactor volume is not limited. They found that the biomass accumulation scales linearly with the amount of charge passed under pure $\mathrm{CO}_{2}$ atmosphere (Fig. 14B) or at ambient $\mathrm{CO}_{2}$ levels (Fig. 14C). The biomass accumulation increases linearly with the increase in the charge, and the linear growth conditions are similar, indicating that the oxidation of hydrogen is the decisive step in the bioelectrical-assisted synthesis process. $R$. eutropha stops growing in the dark cycle and resumes water cracking and con-
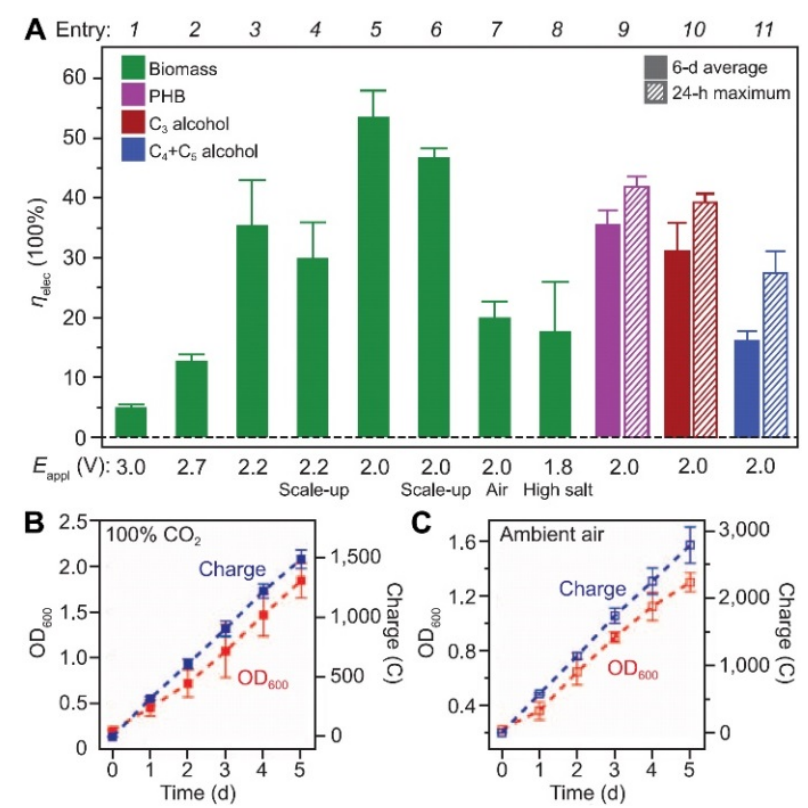

Fig. 14. (A) $\eta_{\text {helec }}$ values for the production of biomass and chemicals at different values of $E_{\text {appl }}$ and for various configurations; (B) Biomass accumulation $\left(\mathrm{OD}_{600}\right)$ and amounts of electric charges that were passed; (C) Real-time monitoring of the biomass accumulation [9]. 
tinuous reduction of $\mathrm{CO}_{2}$ in the light cycle after $12 \mathrm{~h}$ (Fig. 14C), which indicates that the CoPi | Co-P | R. eutropha system can adapt to the intermittency of solar energy. Coupled with the existing photovoltaic system, the energy efficiency is about $50 \%$, which can produce about $10 \% \mathrm{CO}_{2}$ emission reduction efficiency, which exceeds the energy efficiency of the natural photosynthetic system.

To avoid the potentially toxic effect of ROS on cell growth, Chen et al. [139] adopted a two-chamber bioelectrochemical reactor, in which the R. eutropha in the cathodic chamber was separated from the anodic chamber by a proton exchange membrane (PEM). Thus, the ROS produced in the anodic chamber could not penetrate the PEM, which prevented its entry into the cathodic chamber that can poison the cells. To improve the efficiency of $\mathrm{CO}_{2}$ reduction to formate, the researchers constructed an enzyme-assisted NR-mediated MES system by incorporating FDH, which offered two advantages over indium foil cathode for formate formation. On one hand, the cathode potential was only $-0.6 \mathrm{~V}(v s . \mathrm{Ag} / \mathrm{AgCl})$, which was much higher than the $-1.6 \mathrm{~V}(v s . \mathrm{Ag} / \mathrm{AgCl})$ for the system of inorganic electrocatalysts. Thus, the electrical power consumption could be tremendously reduced at such a low overpotential. On the other hand, the electron transport from the cathode into $R$. eutropha was increased, since NR played the role of an electron shuttle and formate acted as an electron carrier. The reduced NR diffused directly into $R$. eutropha through pathway I (electron transfer mechanism mediated by NR), thus increasing the level of intracellular reduction equivalents and further improving the efficiency of MES. NR also promoted the extracellular regeneration of NADH and effectively promoted the reduction of $\mathrm{CO}_{2}$ to formic acid, catalyzed by $\mathrm{FDH}$, in the cathode chamber. Formic acid then transferred to R. eutropha via pathway II (formic acid-mediated electron transfer mechanism) as an electron carrier, and an efficient CBB cycle devel-

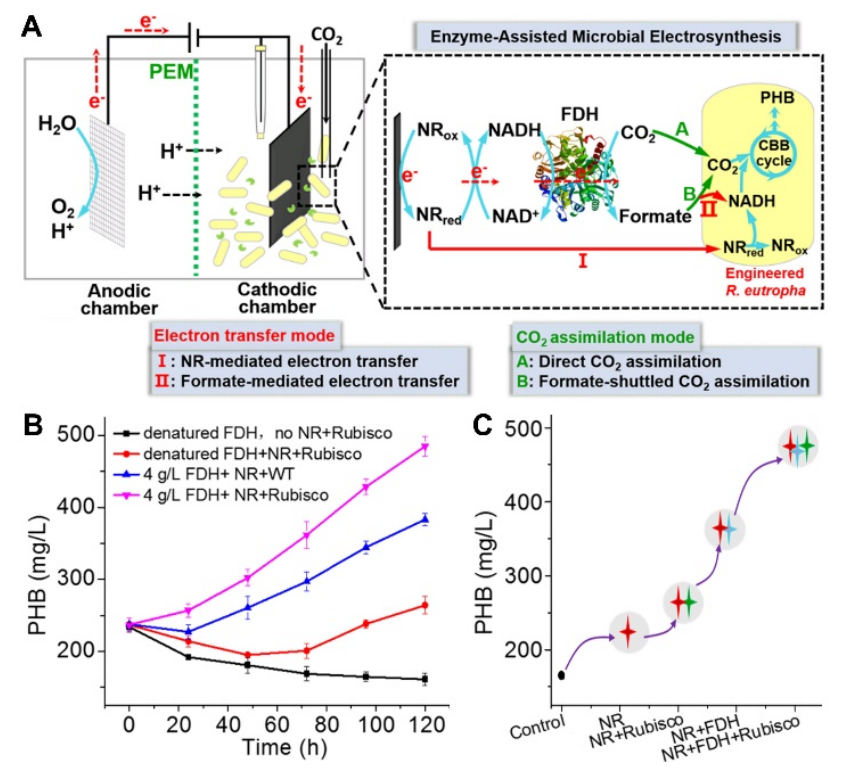

Fig. 15. (A) Schematic of FDH-assisted MES to reduce $\mathrm{CO}_{2}$ to synthesize PHB; (B) PHB yields in WT R. eutropha and RuBisCO-overexpressed $R$. eutropha; (C) Enhancement in PHB production with gradual optimization of the MES process [139]. oped by the heterologous expression of RuBisCO to synthesize PHB, as shown in Fig. 15A [140]. $485 \mathrm{mg} \mathrm{L}^{-1}$ of PHB was synthesized by the RuBisCO overexpressed $R$. eutropha, while only $383 \mathrm{mg} \mathrm{L}^{-1}$ of PHB was synthesized by WT R eutropha (Fig. 15B). In Fig. 14C, $0.05 \mathrm{~mm}$ NR was added to MES; WT $R$. eutropha produced $226 \mathrm{mg} \mathrm{L}^{-1} \mathrm{PHB}$. However, when $R$. eutropha was introduced into RuBisCO, only $156 \mathrm{mg} \mathrm{L}^{-1}$ of PHB accumulated. With the incorporation of FDH, $485 \mathrm{mg} \mathrm{L}^{-1}$ of PHB could be synthesized by R. eutropha in the FDH-assisted MES system. $383 \mathrm{mg} \mathrm{L}^{-1}$ of PHB was synthesized by WT R. eutropha.

\subsubsection{Isopropanol}

Torella et al. [10] designed an integrated inorganic-biological hybrid system to achieve an overall efficiency comparable to or exceeding that of a natural system at low overpotentials. In this work, the system has been engineered based on the CoPi water-splitting anode, with NiMoZn or stainless-steel (304 mesh 60) as the cathode, to generate $\mathrm{H}_{2}$ by electrolysis of water. The biosynthetic process of isopropanol $\left(\left(\mathrm{CH}_{3}\right)_{2} \mathrm{CHOH}\right)$ is shown in Fig. 16A; $R$. eutropha $\mathrm{H} 16$ oxidizes $\mathrm{H}_{2}$ with hydrogenases to produce NADPH and ATP. Then, $\mathrm{CO}_{2}$ is reduced to 3-phosphoglycerate (3PG) by Calvin cycle. The 3PG is rapidly converted to PHB by acetyl-coenzyme A as follow. In the synthesis of PHB, the strain Re2133-pEG12 was destroyed and four genes that redirected acetyl-coenzyme A to synthesize isopropanol were expressed. Plasmid pEG12 expressed genes from ketosulfide ( $p h a A^{*}$ ) and acetic acid-CoA transferase (ctf) of $R$. eutropha, as well as acetoacetic acid decarboxylase and ADH from Clostridium sp. Through the action of these enzymes, 3PG is transferred to isopropanol in Re2133-pEG12 (Fig. 16B). The yield of isopropanol was $216 \mathrm{mg} \mathrm{L}^{-1}$ after 5 days, and the
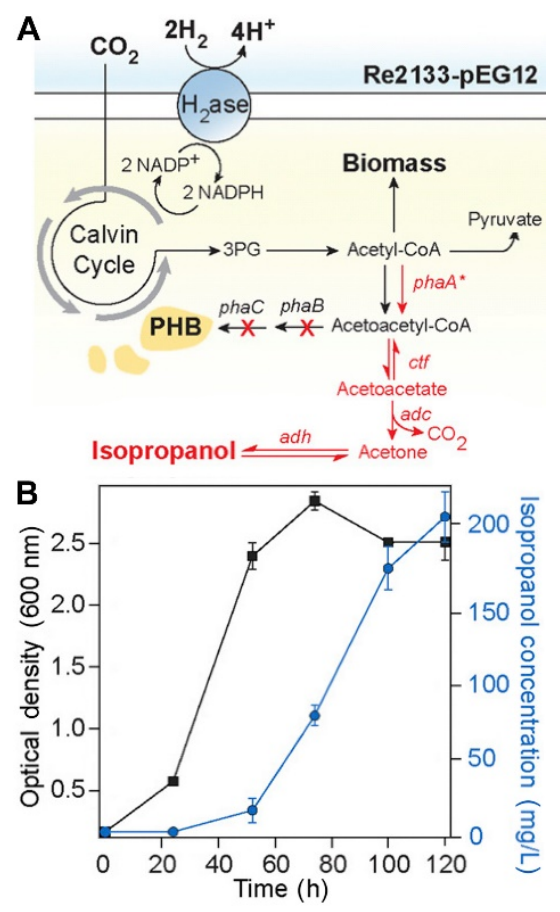

Fig. 16. (A) Engineered pathway for isopropanol production; (B) Growth and isopropanol production in Re2133-pEG12 grown at $3.0 \mathrm{~V}$ [10]. 
byproducts pyruvate $\left(17 \mathrm{mg} \mathrm{L}^{-1}\right)$ and acetone $\left(10 \mathrm{mg} \mathrm{L}^{-1}\right)$ were also produced, with the maximum bioelectrochemical efficiency being $3.9 \%$.

\subsubsection{Acetone}

Ketones are important organic compounds. Acetone, as the simplest ketone, is widely used as a solvent or precursor of industrial chemicals. Zhou et al. [141] reported a biological process using $\mathrm{CO}_{2}$ to produce acetone $\left(\mathrm{CH}_{3} \mathrm{COCH}_{3}\right)$. An exogenous $\mathrm{CO}_{2}$ synthesis pathway was introduced into Synechocystis $s p$. PCC 6803 to construct the modular synthesis pathway of acetone biosynthesis. In this work, $36.0 \mathrm{mg} \mathrm{L}^{-1}$ acetone could be produced. Li et al. [142] designed a kind of R. eutropha H16 in the electro-bioreactor that can fix $\mathrm{CO}_{2}$ through genetic engineering. The produced fuel yield was more than $1.4 \mathrm{~g} \mathrm{~L}^{-1}(\sim 846$ $\mathrm{mg} \mathrm{L}^{-1}$ isobutanol and $\sim 570 \mathrm{mg} \mathrm{L}^{-1} 3$-methyl-1-butanol).

\subsubsection{Butyric acid}

Ganigué et al. [143] demonstrated for the first time the bioelectrochemical synthesis of butyric acid $\left(\mathrm{CH}_{3}\left(\mathrm{CH}_{2}\right)_{2} \mathrm{COOH}\right)$ by using $\mathrm{CO}_{2}$ as the sole carbon source. The maximum concentration of butyric acid was $20.2 \mathrm{mMC}$, and the maximum yield 1.82 $\mathrm{mMC} \mathrm{d}^{-1}$. Production of bioethanol (ethanol and butanol) from $\mathrm{CO}_{2}$ was also observed. In 2017, Batlle-Vilanova et al. [144] used the tubular bioelectrochemical system and mixed cultured microbial community to increase the yield of butyric acid. The authors suggested that chain extension with acetic acid and ethanol as the main raw materials was the main hypothesis for the production of butyric acid. The maximum yield of butyric acid was $7.2 \mathrm{mmol} \mathrm{L}^{-1} \mathrm{~d}^{-1}$, and the concentration of butyric acid was up to $252.4 \mathrm{mmol} \mathrm{L}^{-1}$. when tested at a fixed cathodic potential of $-0.8 \mathrm{~V}$ ( $v s$. SHE). The yields of other products (acetic acid, ethanol, and butanol) were low.

\subsubsection{Isoprene}

Isoprene $\left(\mathrm{CH}_{2} \mathrm{C}\left(\mathrm{CH}_{3}\right) \mathrm{CHCH}_{2}\right)$ is an important component of synthetic rubber, which is produced entirely from petrochemical raw materials. Previous studies on metabolic engineering mainly focused on the heterologous expression of metabolic pathways [145-147]. In order to directly produce isoprene from $\mathrm{CO}_{2}$, Gao et al. [148] developed the methylerythritol phosphate biosynthesis pathway for isoprene in cyanobacteria in 2016. The isoprene synthetase with a high activity from plants was used to improve the production activity of isoprene. The engineering strain orientated about $40 \%$ of the photosynthetically fixed carbon to the isoprene biosynthesis pathway and produced $1.26 \mathrm{~g} \mathrm{~L}^{-1}$ of isoprene from $\mathrm{CO}_{2}$.

\section{Conclusions and perspectives}

This paper summarized the recent progresses in $\mathrm{CO}_{2}$ artificial biotransformation. The key techniques, including microbial electrosynthesis, photosynthetic biohybrid systems, PSII hybrid system, and metabolic engineering, were introduced. The various chemicals synthesized from these techniques were discussed in detail from the aspects of hybrid systems and the possible mechanisms.
On the basis of the current status of $\mathrm{CO}_{2}$ artificial bioconversion, we present several future prospects and directions for possible applications.

(1) The electron transfer mechanism involved in the process of $\mathrm{CO}_{2}$ artificial biotransformation has not been confirmed, and this process has not been understood clearly and in-depth. Only by mastering these core disciplines and reaction mechanisms can we design and construct an efficient artificial biotransformation system for $\mathrm{CO}_{2}$. Only then can we really promote the research of sustainable energy production and solve the environmental problem associated with $\mathrm{CO}_{2}$.

(2) $\mathrm{CO}_{2}$ is a very stable molecule and its activation is a fundamental challenge because the carbon atom in the molecule is in the highest oxidation state, that is, it is in the lowest energy state. The process of converting inorganic carbon to organic carbon requires a lot of energy and reducing power. According to the standard redox potential shown in equations (1)-(6) and the multi-electron reduction steps of $\mathrm{CO}_{2}$, the products of $\mathrm{CO}_{2}$ reduction can be transformed to different compounds and target products with different carbon chain lengths can be obtained.

(3) We should fully develop efficient catalysts that are composed of earth-abundant elements. These catalysts should display the advantages of low cost, good biocompatibility, high conductivity, high specific surface area, and generality. This is an important prerequisite to realize large-scale conversion and utilization of $\mathrm{CO}_{2}$ with renewable energy.

(4) By understanding the diversity of carbon sequestration organisms and their metabolic pathways in nature and discovering efficient carbon sequestration elements, microorganisms can be modified with various metabolic pathways to realize the design of a carbon sequestration pathway of converting $\mathrm{CO}_{2}$ to target products.

Research on artificial biotransformation of $\mathrm{CO}_{2}$ has been growing, and great breakthroughs have been made in related fields. This important technology will make use of the most extensive renewable resource on the planet, $\mathrm{CO}_{2}$, to address the environmental and energy problems efficiently and in a green fashion. In the future, biocompatible solid-state nano-devices can be combined with living systems, and the acetic acid obtained through artificial bioconversion of $\mathrm{CO}_{2}$ can continue to be activated to acetoacetyl-CoA by downstream genetically engineered E.coli and used as a building block for a variety of value-added chemicals such as n-butanol, PHB polymer, and three different isoprenoid natural products.

\section{References}

[1] U. N., World Economic Situation and Prospects (Zhongguo Caizheng), 2018.

[2] B. C. O'Neill, M. Oppenheimer, Science, 2002, 296, 1971-1972.

[3] J. Wu, X. D. Zhou, Chin. J. Catal., 2016, 37, 999-1015.

[4] B. James, Chem. Soc. Rev., 2009, 38, 185-196.

[5] H. Li, J. C. Liao, Energy Environ. Sci., 2013, 6, 2892-2899.

[6] L. Wei, Q. Wang, Y. Xin, Y. Lu, J. Xu, Algal Res., 2017, 27, 366-375.

[7] C. Wu, Y. Zhou, Z. Zou, Chin. J. Catal., 2011, 32, 1565-1572.

[8] L. Shi, G. H. Yang, K. Tao, Y. Yoneyama, Y. S. Tan, N. Tsubaki, Acc. Chem. Res., 2013, 48, 1838-1847. 


\section{Graphical Abstract}

Chin. J. Catal., 2019, 40: 1421-1437 doi: S1872-2067(19)63408-X

\section{Artificial bioconversion of carbon dioxide}

Ting-Ting Zhao, Guang-Hui Feng, Wei Chen*, Yan-Fang Song, Xiao Dong, Gui-Hua Li, Hai-Jiao Zhang, Wei Wei*

Shanghai University; Shanghai Advanced Research Institute, Chinese Academy of Sciences; ShanghaiTech University

The $\mathrm{CO}_{2}$ artificial bioconversion system, in which $\mathrm{CO}_{2}$ is converted into value-added chemicals via the metabolic pathway in organisms, is driven by renewable energy.

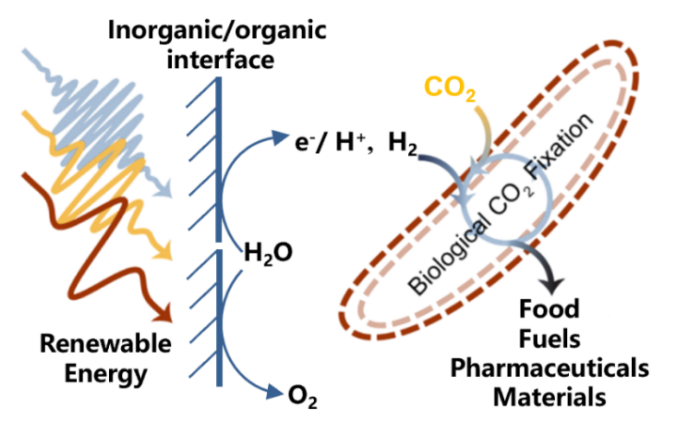

[9] C. Liu, B. C. Colon, M. Ziesack, P. A. Silver, D. G. Nocera, Science, 2016, 352, 1210-1213.

[10] J. P. Torella, C. J. Gagliardi, J. S. Chen, D. K. Bediako, B. Colón, J. C. Way, P. A .Silver, D. G. Nocera, Proc. Natl. Acad. Sci. U. S. A., 2015, $112,2337-2342$.

[11] M. Schreier, L. Curvat, F. Giordano, L. Steier, A. Abate, S. M. Zakeeruddin, J. Luo, M. T. Mayer, M. Grätzel, Nat. Commun., 2015, 6 (7326), 1-6.

[12] M. Schreier, F. Héroguel, L. Steier, S. Ahmad, J. S. Luterbacher, M. T. Mayer, J. Luo, M. Grätzel, Nat. Energy, 2017, 2 (17087), 1-9.

[13] S. Liu, H. Tao, Q. Liu, Z. Xu, Q. Liu, J.-L. Luo, ACS Catal., 2018, 8, 1469-1475.

[14] X. Zheng, B. Zhang, P. De Luna, Y. Liang, R. Comin, O. Voznyy, L. Han, F. P. G. de Arquer, M. Liu, C. T. Dinh, T. Regier, J. J. Dynes, S. He, H. L. Xin, H. Peng, D. Prendergast, X. Du, E. H. Sargent, Nat. Chem., 2018, 10, 149-154.

[15] S. Liu, J. Xiao, X. F. Lu, J. Wang, X. Wang, X. W. Lou, Angew. Chem. Int. Ed., 2019, 58, 8499-8503.

[16] H. J. Shin, K. A. Jung, C. W. Nam, J. M. Park, Bioresour. Technol,, 2017, 245, 1421-1429.

[17] G. Mohanakrishna, K. Vanbroekhoven, D. Pant, React. Chem. Eng., 2018, 3, 371-378.

[18] S. Bajracharya, S. Srikanth, G. Mohanakrishna, R. Zacharia, D. P. B. T. B. Strik, D. Pant, J. Power Sources, 2017, 356, 256-273.

[19] K. P. Nevin, T. L. Woodard, A. E. Franks, Z. M. Summers, D. R. Lovley, Mbio, 2010, 1, e00103-10/1-e00103-10/4, doi: 10.1128/mBio.00103-10

[20] K. K. Sakimoto, N. Kornienko, P. Yang, Acc. Chem. Res., 2017, 50, 476-481.

[21] X. Christodoulou, T. Okoroafor, S. Parry, S. B. Velasquez-Orta, J. $\mathrm{CO}_{2}$ Util., 2017, 18, 390-399.

[22] X. Christodoulou, S. B. Velasquez-Orta, Environ. Sci. Technol,, 2016, $50,11234-11242$.

[23] P. Zhang, Y. Yang, J. Shi, Y. Zheng, L. Wang, X. Li, Renew. Sustain. Energy Rev., 2009, 13, 439-449.

[24] R. E. Blankenship, D. M. Tiede, J. Barber, G. W. Brudvig, G. Fleming, M. Ghirardi, M. R. Gunner, W. Junge, D. M. Kramer, A. Melis, T. A. Moore, C. C. Mosre, D. G. Nocera, A. J. Nozik, D. R. Ort, W. W. Parson, R. C. Prince, R. T. Sayre. Science, 2011, 332, 805-809.

[25] T. Zhang, Science, 2015, 350, 738-739.

[26] H. W. Zhu, Y. P. Zhang, Y. Li, Sci. Sin. Vitae, 2016, 46, 1388-1399.

[27] P. Gao, S. Li, X. Bu, S. Dang, Z. Liu, H. Wang, L. Zhong, M. Qiu, C. Yang, J. Cai, W. Wei, Y. Sun, Nat. Chem., 2017, 9, 1019-1024.
[28] P.-L. Tremblay, T. Zhang, Front. Microbiol., 2015, 6, 201/1-201/10.

[29] J. Du, C. Catania, G. C. Bazan, Chem. Mater, 2014, 26, 686-697.

[30] T. Zhang, H. Nie, T. S. Bain, H. Lu, M. Cui, O. L. Snoeyenbos-West, A. E. Franks, K. P. Nevin, T. P. Russell, D. R. Lovley, Energy Environ. Sci., 2013, 6, 217-224.

[31] K. P. Nevin, S. A. Hensley, A. E. Franks, Z. M. Summers, J. Ou, T. L. Woodard, O. L. Snoeyenbos-West, D. R. Lovley, Appl. Environ. Microbiol., 2011, 77, 2882-2886.

[32] J. Sadhukhan, J. R. Lloyd, K. Scott, G. C. Premier, E. H. Yu, T. Curtis, I. M. Head, Renew. Sustain. Energy Rev., 2016, 56, 116-132.

[33] S. Bajracharya, A. ter Heijne, X. D. Benetton, K. Vanbroekhoven, C. J. N. Buisman, D. P. B. T. B. Strik, D. Pant, Bioresource Technol, 2015, $195,14-24$.

[34] C. W. Marshall, D. E. Ross, E. B. Fichot, N. S. Norman, H. D. May, Environ. Sci. Technol., 2013, 47, 6023-6029.

[35] L. Jourdin, S. Freguia, B. C. Donose, J. Chen, G. G. Wallace, J. Keller, V. Flexer, J. Mater. Chem. A, 2014, 2, 13093-13102.

[36] V. Flexer, J. Chen, B. C. Donose, P. Sherrell, G. G. Wallace, J. Keller, Energy Environ. Sci., 2013, 6, 1291-1298.

[37] N. S. Malvankar, D. R. Lovley, Curr. Opin. Biotechnol., 2014, 27, 88-95.

[38] K. K. Sakimoto, C. Liu, J. Lim, P. Yang, Nano Lett., 2014, 14, 5471-5476.

[39] H. E. Jeong, I. Kim, P. Karam, H.-J. Choi, P. Yang, Nano Lett., 2013, 13, 2864-2869.

[40] G. Z. Ramon, B. J. Feinberg, E. M. V. Hoek, Energy Environ. Sci., 2011, 4, 4423-4434.

[41] R. D. Cusick, Y. Kim, B. E. Logan, Science, 2012, 335, 1474-1477.

[42] X. Li, I. Angelidaki, Y. Zhang, Water Res., 2018, 142, 396-404.

[43] C. Liu, J. Tang, H. M. Chen, B. Liu, P. Yang, Nano Lett., 2013, 13, 2989-2992.

[44] C. Liu, J. J. Gallagher, K. K. Sakimoto, E. M. Nichols, C. J. Chang, M. C. Y. Chang, P. Yang, Nano Lett., 2015, 15, 3634-3639.

[45] N. Kornienko, K. K. Sakimoto, D. M. Herlihy, S. C. Nguyen, A. P. Alivisatos, C. B. Harris, A. Schwartzberg, P. Yang, Proc. Natl. Acad. Sci. U. S. A., 2016, 113, 11750-11755.

[46] Y. Amao, R. Kataoka, Catal. Today, 2018, 307, 243-247.

[47] R. K. Yadav, J.-O. Baeg, A. Kumar, K.-J. Kong, G. H. Oh, N.-J. Park, J. Mater. Chem. A, 2014, 2, 5068-5076.

[48] N. Aryal, A. Halder, P.-L. Tremblay, Q. Chi, T. Zhang, Electrochim. Acta, 2016, 217, 117-122.

[49] Y. Li, Sci. China Mater., 2016, 59, 93-94. 
[50] W. Wang, J. Chen, C. Li, W. Tian, Nat. Commun., 2014, 5, 4647/1-4647/8.

[51] K. Sauer, V. K. Yachandra, Biochim. Biophys. Acta-Bioenerg., 2004, $1655,140-148$.

[52] Y. N. Wang, C. X. Zhang, L. Wang, J. Q. Zhao, Chin. Sci. Bull., 2013, 58, 3213-3216.

[53] W. Wang, Z. Wang, Q. Zhu, G. Han, C. Ding, J. Chen, J. R. Shen, C. Li, Chem. Commun., 2015, 51, 16952-16955.

[54] W. Wang, Z. Li, J. Chen, C. Li, J. Phy. Chem. C, 2017, 121, 2605-2612.

[55] S. Ye, C. Ding, R. Chen, F. Fan, P. Fu, H. Yin, X. Wang, Z. Wang, P. Du, C. Li, J. Am. Chem. Soc., 2018, 140, 3250-3256.

[56] F. Wen, C. Li, Acc. Chem. Res., 2013, 46, 2355-2364.

[57] Y. Li, Chin. J. Biotechnol., 2009, 25, 1281-1284.

[58] J. E. Bailey, Science, 1991, 252, 1668-1675.

[59] M. Koffas, C. Roberge, K. Lee, G. Stephanopoulos, Ann. Rev. Biomed. Eng., 1999, 1, 535-557.

[60] T. Minowa, S. Yokoyama, M. Kishimoto, T. Okakura, Fuel, 1995, 74, 1735-1738.

[61] S. Hirayama, R. Ueda, Y. Ogushi, A. Hirano, Y. Samejima, K. Hon-Nami, S. Kunito, Stud. Surf. Sci. Catal, 1998, 114, 657-660.

[62] L. Wei, Y. Xin, Q. Wang, J. Yang, H. Hu, J. Xu, Plant J., 2017, 89, 1236-1250.

[63] M. Liu, Y. Ding, H. Chen, Z. Zhao, H. Liu, M. Xian, G. Zhao, BMC Microbiol., 2017, 17, 10/1-10/9.

[64] F. Gong, Z. Cai, Y. Li, Sci. China Life Sci., 2016, 59, 1106-1114.

[65] A. Bar-Even, E. Noor, N. E. Lewis, R. Milo, Proc. Natl. Acad. Sci. U. S. A., 2010, 107, 8889-8894.

[66] M. S. Khan, Trends Biotechnol., 2007, 25, 437-440.

[67] Y. Marcus, H. Altman-Gueta, Y. Wolff, M. Gurevitz, J. Exp. Bot., 2011, 62, 4173-4182.

[68] D. M. Kramer, J. R. Evans, Plant Physiol., 2011, 155, 70-78.

[69] J. R. Evans, Plant Physiol., 2013, 162, 1780-1793.

[70] J. Zhou, F. Zhang, H. Meng, Y. Zhang, Y. Li, Metab. Eng., 2016, 38, 217-227.

[71] F. Liang, P. Lindblad, Metab. Eng. Commun., 2017, 4, 29-36.

[72] E. Herz, N. Antonovsky, Y. Bar-On, D. Davidi, S. Gleizer, N. Prywes, L. Noda-Garcia, K. L. Frisch, Y. Zohar, D. G. Wernick, A. Savidor, U. Barenholz, R. Milo, Nat. Commun., 2017, 8, 1705/1-1705/10.

[73] N. Antonovsky, S. Gleizer, E. Noor, Y. Zohar, E. Herz, U. Barenholz, L. Zelcbuch, S. Amram, A. Wides, N. Tepper, D. David, Y. Bar-On, T. Bareis, D. G. Wemick, I. Shani, S. Malitsky, G. Jona, A. Bar-Even, R. Milo, Cell, 2016, 166, 115-125.

[74] T. O. Yeates, N. M. Wheatley, Science, 2017, 358, 1253-1254.

[75] H. Aigner, R. H. Wilson, A. Bracher, L. Calisse, J. Y. Bhat, F. U. Hartl, M. Hayer-Hartl, Science, 2017, 358, 1272-1278.

[76] S. Schlager, A. Fuchsbauer, M. Haberbauer, H. Neugebauer, N. S. Sariciftci, J. Mater. Chem. A, 2017, 5, 2429-2443.

[77] F. Marpani, M. Pinelo, A. S. Meyer, Biochem. Eng. J., 2017, 127, 217-228.

[78] K. Kalyanasundaram, M. Graetzel, Curr. Opin. Biotechnol., 2010, 21, 298-310.

[79] Y. Surendranath, D. K. Bediako, D. G. Nocera, Proc. Natl. Acad. Sci. U. S. A., 2012, 109, 15617-15621.

[80] D. G. Nocera, Acc. Chem. Res., 2012, 45, 767-776.

[81] G. A. Olah, A. Goeppert, G. K. S. Prakash, Beyond Oil and Gas: The Methanol Economy, 2nd ed., Wiley-VCH, Weinheim, 2009.

[82] R. Obert, B. C. Dave, J. Am. Chem. Soc., 1999, 121, 12192-12193.

[83] S.-W. Xu, Y. Lu, J. Li, Z.-Y. Jiang, H. Wu, Ind. Eng. Chem. Res., 2006, $45,4567-4573$.

[84] M. Aresta, A. Dibenedetto, C. Pastore, Environ. Chem. Lett., 2005, 3, 113-117.

[85] P. K. Addo, R. L. Arechederra, S. D. Minteer, Electroanalysis, 2010,
$22,807-812$

[86] J.-H. Jeoung, H. Dobbek, Science, 2007, 318, 1461-1464.

[87] M. Villano, F. Aulenta, C. Ciucci, T. Ferri, A. Giuliano, M. Majone, Bioresource Technol., 2010, 101, 3085-3090.

[88] S. Cheng, D. Xing, D. F. Call, B. E. Logan, Environ. Sci. Technol., 2009, 43, 3953-3958.

[89] S. Schlager, L. M. Dumitru, M. Haberbauer, A. Fuchsbauer, H. Neugebauer, D. Hiemetsberger, A. Wagner, E. Portenkirchner, N. S. Sariciftci, ChemSusChem, 2016, 9, 631-635.

[90] T. W. Woolerton, S. Sheard, E. Pierce, S. W. Ragsdale, F. A. Armstrong, Energy Environ. Sci., 2011, 4, 2393-2399.

[91] T. W. Woolerton, S. Sheard, E. Reisner, E. Pierce, S. W. Ragsdale, F. A. Armstrong, J. Am. Chem. Soc., 2010, 132, 2132-2133.

[92] L. Dan, G. Feng, S. Fan, J. Microbiol., 2003, 23(6), 42-46.

[93] K. Manthiram, B. J. Beberwyck, A. P. Alivisatos, J. Am. Chem. Soc., 2014, 136, 13319-13325.

[94] Y. Hori, I. Takahashi, O. Koga, N. Hoshi, J. Phys. Chem. B, 2002, $106,15-17$

[95] S. Cheng, D. Xing, D. F. Call, B. E. Logan, Environ. Sci. Technol,, 2009, 43, 3953-3958.

[96] E. M. Nichols, J. J. Gallagher, C. Liu, Y. Su, J. Resasco, Y. Yu, Y. Sun, P. Yang, M. C. Y. Chang, C. J. Chang, Proc. Natl. Acad. Sci. U. S. A., 2015, 112, 11461-11466.

[97] J. Song, Y. Kim, M. Lim, H. Lee, J. I. Lee, W. Shin, ChemSusChem, 2011, 4, 587-590.

[98] S. Y. Lee, S. Y. Lim, D. Seo, J.-Y. Lee, T. D. Chung, Adv. Energy Mater., 2016, 6, 1502207.

[99] J. Shi, C. Yang, S. Zhang, X. Wang, Z. Jiang, W. Zhang, X. Song, Q. Ai, C. Tian, ACS Appl. Mater. Interfaces, 2013, 5, 9991-9997.

[100] D. R. Dreyer, D. J. Miller, B. D. Freeman, D. R. Paul, C. W. Bielawski, Chem. Sci., 2013, 4, 3796-3802.

[101] K. Kang, S. Lee, R. Kim, I. S. Choi, Y. Nam, Angew. Chem. Int. Ed., 2012, 51, 13101-13104.

[102] F. Jin, X. Zeng, J. Liu, Y. Jin, L. Wang, H. Zhong, G. Yao, Z. Huo, Sci. Rep., 2014, 4, 4503/1-4503/8.

[103] N. S. Lewis, D. G. Nocera, Proc. Natl. Acad. Sci. U. S. A., 2006, 103, 15729-15735.

[104] Y. Amao, M. Fujimura, M. Miyazaki, A. Tadokoro, M. Nakamura, N. Shuto, New J. Chem., 2018, 42, 9269-9280.

[105] J. Liu, R. Cazelles, Z. P. Chen, H. Zhou, A. Galarneau, M. Antonietti, Phys. Chem. Chem. Phys., 2014, 16, 14699-14705.

[106] K. Ma, O. Yehezkeli, E. Park, J. N. Cha, ACS Catal., 2016, 6, 6982-6986.

[107] R. K. Yadav, G. H. Oh, N.-J. Park, A. Kumar, K. Kong, J.-O. Baeg, J. Am. Chem. Soc., 2014, 136, 16728-16731.

[108] R. K. Yadav, J. O. Baeg, G. H. Oh, N. J. Park, K. Kong, J. Kim, D. W. Hwang, S. K. Biswas, J. Am. Chem. Soc., 2012, 134, 11455-11461.

[109] Y. Xu, Z. Liu, X. Zhang, Y. Wang, J. Tian, Y. Huang, Y. Ma, X. Zhang, Y. Chen, Adv. Mater., 2009, 21, 1275-1279.

[110] 0. Heichal-Segal, S. Rappoport, S. Braun, Bio/Technology, 1995, 13, 798-800.

[111] Z. Lian, D. Pan, W. Wang, D. Zhang, G. Li, H. Li, J. Environ. Sci,, 2017, 60, 108-113.

[112] H. Huber, M. Gallenberger, U. Jahn, E. Eylert, I. A. Berg. D. Kockelkorn. W. Eisenreich. G. Fuchs, Proc. Natl. Acad. Sci. U. S. A., 2008, 105, 7851-7856.

[113] E. Blanchet, F. Duquenne, Y. Rafrafi, L. Etcheverry, B. Erable, A. Bergel, Energy Eviron. Sci., 2015, 8, 3731-3744.

[114] F. Ammam, P.-L. Tremblay, D. M. Lizak, T. Zhang, Biotechnol. Biofuels, 2016, 9, 163/1-163/10.

[115] H. Nie, T. Zhang, M. Cui, H. Lu, D. R. Lovley, T. P. Russell, Phys. Chem. Chem. Phys., 2013, 15, 14290-14294. 
[116] T. Song, K. Fei, H. Zhang, H. Yuan, Y. Yang, P. Ouyang, J. Xie, J. Chem. Technol. Biotechnol., 2018, 93, 457-466.

[117] B. Bian, M. F. Alqahtani, K. P. Katuri, D. Liu, S. Bajracharya, Z. Lai, K. Rabaey, P. E. Saikaly, J. Mater. Chem. A, 2018, 6, 17201-17211.

[118] C. Lu, H. Bai, B. Wu, F. Su, J. F. Hwang, Energy Fuels, 2008, 22, 3050-3056.

[119] M. Rahimi, J. K. Singh, F. Müller-Plathe, J. Phys. Chem. C, 2015, 119, 15232-15239.

[120] M. Rahimi, J. K. Singh, D. J. Babu, J. J. Schneider, F. Müller-Plathe, J. Phys. Chem. C, 2013, 117, 13492-13501.

[121] Y. Zheng, Y. Jiao, Y. Zhu, H. L. Li, Y. Han, Y. Chen, A. Du, M. Jaroniec, S. Z. Qiao, Nat. Commun., 2014, 5, 3783/1-3783/8.

[122] M. C. Y. Chang, R. A. Eachus, W. Trieu, D.-K. Ro, J. D. Keasling, Nat. Chem. Biol., 2007, 3, 274-277.

[123] J. D. Keasling, Science, 2010, 330, 1355-1358.

[124] K. K. Sakimoto, S. J. Zhang, P. Yang, Nano Lett., 2016, 16, 5883-5887.

[125] V. Mueller, Science, 2016, 351, 34.

[126] K. K. Sakimoto, A. B. Wong, P. Yang, Science, 2016, 351, 74-77.

[127] A. Hirano, R. Ueda, S. Hirayama, Y. Ogushi, Energy, 1997, 22, 137-142.

[128] M. De Deng, J. R. Coleman, Appl. Environ. Microbiol., 1999, 65, 523-528.

[129] T. Kaneko, S. Tabata, Plant Cell Physiol., 1997, 38, 1171-1176.

[130] J. Dexter, P. Fu, Energy Environ. Sci., 2009, 2, 857-864.

[131] Z. Gao, H. Zhao, Z. Li, X. Tan, X. Lu, Energy Environ. Sci., 2012, 5, 9857-9865.

[132] J. Kopka, S. Schmidt, F. Dethloff, N. Pade, S. Berendt, M. Schottkowski, N. Martin, U. Dühring, E. Kuchmina, H. Enke, Biotechnol. Biofuels, 2017, 10, 56/1-56/21.
[133] A. Pohlmann, W. F. Fricke, F. Reinecke, B. Kusian, H. Liesegang, R. Cramm, T. Eitinger, C. Ewering, M. Pötter, E. Schwartz, A. Strittmatter, I. Voß, G. Gottschalk, A. Steinbüchel, B. Friedrich, B. Bowien, Nat. Biotechnol., 2006, 24, 1257-1262.

[134] M. Calvin, A. A. Benson, Science, 1949, 109, 140-142.

[135] A. J. Esswein, Y. Surendranath, S. Y. Reece, D. G. Nocera, Energy Environ. Sci., 2011, 4, 499-504.

[136] D. R. Lovley, Environ. Microbiol. Rep., 2011, 3, 27-35.

[137] K. Rabaey, R. A. Rozendal, Nat. Rev. Microbiol., 2010, 8, 706-716.

[138] S. Y. Reece, J. A. Hamel, K. Sung, T. D. Jarvi, A. J. Esswein, J. J. H. Pijpers, D. G. Nocera, Science, 2011, 334, 645-648.

[139] X. Chen, Y. Cao, F. Li, Y. Tian, H. Song, ACS Catal., 2018, 8, $4429-4437$.

[140] G. G. B. Tcherkez, G. D. Farquhar, T. J. Andrews, Proc. Natl. Acad. Sci. U. S. A., 2006, 103, 7246-7251.

[141] J. Zhou, H. Zhang, Y. Zhang, Y. Li, Y. Ma, Metab. Eng., 2012, 14, 394-400.

[142] H. Li, P. H. Opgenorth, D. G. Wernick, S. Rogers, T.-Y. Wu, W. Higashide, P. Malati, Y.-X. Huo, K. M. Cho, J. C. Liao, Science, 2012, 335, 1596.

[143] R. Ganigué, S. Puig, P. Batlle-Vilanova, M. D. Balaguer, J. Colprim, Chem. Commun., 2015, 51, 3235-3238.

[144] P. Batlle-Vilanova, R. Ganigué, S. Ramió-Pujol, L. Bañeras, G. Jiménez, M. Hidalgo, M. D. Balaguer, J. Colprim, S. Puig, Bioelectrochemistry, 2017, 117, 57-64.

[145] E. I. Lan, J. C. Liao, Metab. Eng., 2011, 13, 353-363.

[146] V. J. J. Martin, D. J. Pitera, S. T. Withers, J. D. Newman, J. D. Keasling, Nat. Biotechnol., 2003, 21, 796-802.

[147] P. Lindberg, S. Park, A. Melis, Metab. Eng., 2010, 12, 70-79.

[148] X. Gao, F. Gao, D. Liu, H. Zhang, X. Nie, C. Yang, Energy Environ. Sci., 2016, 9, 1400-1411.

\section{二氧化碳的人工生物转化 \\ 赵婷婷 ${ }^{\mathrm{a}, \mathrm{b}}$, 冯光辉 ${ }^{\mathrm{a}, \mathrm{b}}$, 陈 为 ${ }^{\mathrm{b},{ }^{*}}$, 宋艳芳 ${ }^{\mathrm{b}}$, 董 笑 ${ }^{\mathrm{b}}$, 李桂花 ${ }^{\mathrm{b}}$, 张海娇 ${ }^{\mathrm{a}}$, 魏 伟 ${ }^{\mathrm{b}, \mathrm{c}, \text {, }}$ ${ }^{\mathrm{a}}$ 上海大学环境与化学工程学院, 上海 200444 \\ ${ }^{b}$ 中国科学院上海高等研究院, 中国科学院低碳转化科学与工程重点实验室, 上海201210 \\ ${ }^{\mathrm{c}}$ 上海科技大学物质科学与技术学院, 上海 201210}

摘要: $\mathrm{CO}_{2}$ 是最主要的温室气体, 也是重要的碳氧资源. 从资源和能源发展战略角度, 利用低品阶可再生能驱动 $\mathrm{CO}_{2}$ 转化合 成化学品, 将为 $\mathrm{CO}_{2}$ 资源化利用和可再生能转化并存储为化学能提供极大的发展空间, 具有重大意义. 目前, 利用可再生能 光电催化 $\mathrm{CO}_{2}$ 转化利用的研究方兴未艾, 而人工生物转化 $\mathrm{CO}_{2}$ 作为重要的合成化学品新途径也受到越来越多的关注. 通过 模拟自然界中植物和微生物等的自然光合作用过程, 设计和构建出人工光合体系, 可使人工生物转化 $\mathrm{CO}_{2}$ 以更加高效的方 式转化 $\mathrm{CO}_{2}$ 合成化学品. 人工生物转化 $\mathrm{CO}_{2}$ 合成化学品是电催化、光催化和光电催化 $\mathrm{CO}_{2}$ 等过程的重要补充, 主要包括微生 物电合成、无机-生物杂化光合系统、PSII复合体系和代谢工程等关键技术.

微生物电合成(microbial electrosynthesis, MES) 是在生物电化学系统中利用特定的微生物作为生物催化剂, 以电能作为 能量输入, 通过生物反应将 $\mathrm{CO}_{2}$ 还原成多碳化合物的最有前途的新兴技术之一. 用于MES的细菌和酶具备合成单一产物的 功能, 对于合成目标产物具有 $100 \%$ 的选择性. 以太阳能、风能等低品阶可再生电能作为其驱动能量, 从而使MES成为一种 更绿色和可持续的 $\mathrm{CO}_{2}$ 转换技术. MES中 $\mathrm{CO}_{2}$ 转化为高附加值化学品和生物燃料仍处于初步阶段, 有许多技术和经济挑战 需要解决, 如低能量利用效率和 $\mathrm{CO}_{2}$ 转化率.

无机-生物杂化光合体系(photosynthetic biohybrid systems, $\mathrm{PBS}_{\mathrm{S}}$ ) 是由细菌或酶固定在无机半导体光催化剂上组成的新 型光驱动装置, 将高效无机光催化剂与酶催化剂或细胞有机体结合起来, 以接近或超过自然光合作用或单独化学催化的效 率选择性地固定 $\mathrm{CO}_{2} . \mathrm{PBS}_{\mathrm{S}}$ 可在温和条件下以成本效益高的方式高选择性获得目标产物, 并且具有合成大量长链碳分子的 能力. 该装置也可以理解为是MES反应器以太阳能为动力, 或对MES电极进行改造, 使其能够直接捕获光能, 从而有效地 成为一种比天然光合作用具有更高太阳能效率的人工光合作用装置. $\mathrm{PBS}_{\mathrm{s}}$ 目前还处于发展的初级阶段, 虽然可以获得更 
高的太阳能转换效率 $(10 \%-20 \%)$, 但进行实际应用仍有不少困难. 其中主要的挑战在于选择可兼容的光采集系统和高效的 生物固碳元件, 以及生物和非生物组分的无缝集成, 即要克服跨生物和非生物界面上的电荷转移屏障.

PSII复合体系是最近提出来的一种由天然光合系统二(photosynthetic system II, PSII)和人工光催化剂组成的, 或用PSII 对MES电极进行修饰, 辅助MES对 $\mathrm{CO}_{2}$ 还原的人工光化学体系. 与 $\mathrm{PBS}_{\mathrm{S}}$ 相比, PSII复合体系的生物酶是PSII, 可以再现PSII 的生物特征如优秀的光采集能力, PSII可以高效捕获可见太阳光光谱所有波长的能量, 并且有效地利用该能量驱动水分解 产氢, 这也是无机光催化剂不具有的优势. 研究人员对利用PSII组装在电极上的光伏转换系统进行了大量研究, 并将其应 用于 $\mathrm{CO}_{2}$ 光电化学合成, 目前已取得初步进展.

代谢工程(metabolic engineering)是根据细胞代谢网络对细胞代谢途径进行合理设计, 并利用分子生物学手段如重组 DNA技术有目的地设计和调控生物体中已有的代谢网络和表达调控网络, 从而实现更高效的生物化学转化、能量转移以及 积累目标产物的应用学科. 目前, 代谢工程被大量应用于光合生物固碳, 进一步优化 $\mathrm{CO}_{2}$ 到生物量或其他有机碳化合物的 资源化利用. 通过对代谢工程的研究, 提高认识、设计和改造细胞代谢 $\mathrm{CO}_{2}$ 的能力, 从而获得低能耗、高效率的固碳途径, 推 动生物固碳工业技术进步.

本文总结了近年来基于上述 $\mathrm{CO}_{2}$ 人工生物转化关键技术在合成不同碳数化合物方面所取得的重要研究成果, 并对其未 来发展趋势进行了展望.

关键词: 二氧化碳; 人工生物转化; 太阳能; 固碳; 化合物

收稿日期: 2019-03-23. 接受日期: 2019-05-11. 出版日期: 2019-10-05.

*通讯联系人. 电话: (021)20350954; 传真: (021)20350867; 电子信箱: chenw@sari.ac.cn

通讯联系人. 电话: (021)20608005; 传真: (021)20350867; 电子信箱: weiwei@sari.ac.cn

基金来源: 国家自然科学基金(91745114, 21802160); 国家重点研发计划(2016YFA0202800); 中国科学院百人计划; 上海市扬帆 计划(18YF1425700); 中国科学院上海高等研究院创新基金(Y756812ZZ1(172002), Y756803ZZ1(171003)).

本文的电子版全文由Elsevier出版社在ScienceDirect上出版(http://www.sciencedirect.com/science/journal/18722067). 